\title{
Prion Protein: Orchestrating Neurotrophic Activities
}

\author{
Vilma R. Martins ${ }^{1 \# *}$, Flavio H. Beraldo ${ }^{1 \#, ~ G l a u c i a ~ N . ~ H a j j ~}{ }^{1 \#,}$ \\ Marilene H. Lopes ${ }^{1 \#}$, Kil Sun Lee ${ }^{2}$, Marco A. Prado ${ }^{3,4}$ and \\ Rafael Linden ${ }^{5}$ \\ ${ }^{1}$ Ludwig Institute for Cancer Research, Hospital Alemão \\ Oswaldo Cruz, São Paulo, SP, Brazil \\ ${ }^{2}$ Associação Fundo de Incentivo à Psicofarmacologia, São \\ Paulo, SP, Brazil \\ ${ }^{3}$ Robarts Research Institute, Departments of Anatomy and \\ Cell Biology/Physicology and Pharmacology, University of \\ Western Ontario, London, Ontario, Canada. \\ ${ }^{4}$ Department of Pharmacology, Federal University of Minas \\ Gerais, MG, Brazil. \\ ${ }^{5}$ Instituto de Biofísica Carlos Chagas Filho, Universidade \\ Federal do Rio de Janeiro, Rio de Janeiro, RJ, Brazil.
}

\begin{abstract}
$\mathrm{PrP}^{\mathrm{C}}$ is highly expressed in both the central and peripheral nervous systems from early stages of development and in adulthood. Its major conformational change and conversion into an abnormal form ( $\mathrm{PrP}^{\mathrm{Sc}}$ ) has been associated with the generation of prions, the infectious agent of transmissible spongiform encephalopathies (TSEs). The massive neurodegeneration presented by individuals suffering from these diseases has been associated with the gain of neurotoxic activity of $\mathrm{PrP}^{\mathrm{Sc}}$. On the other hand, major neurodegeneration is also observed in transgenic mice expressing $\mathrm{PrPC}^{\mathrm{C}}$ molecules deleted of specific domains, which points to important functional domains within this molecule, and supports the hypothesis that loss-of $\mathrm{PrPC}^{\mathrm{C}}$ function may contribute to the pathogenesis of TSEs. Furthermore, a large body of data demonstrates direct or indirect interaction of $\mathrm{PrP}^{\mathrm{C}}$ with extracellular matrix proteins, soluble factors, transmembrane proteins, G-protein coupled receptors and ions channels. The ability of $\mathrm{PrP}^{\mathrm{C}}$ to drive the assembly of multi-component complexes at the cell surface is likely the basis for its neurotrophic functions. These properties indicate that $\mathrm{PrPC}^{\mathrm{C}}$ may be relevant for not only the spongiform encephalophaties, but also as an ancillary component of the pathogenesis of other neurodegenerative diseases, and therefore amenable to therapeutic targeting.
\end{abstract}

\section{The prion protein and the neurotrophic theory}

The neurotrophic theory originally referred to the idea that all body organs were dependent on nutritional factors secreted by the nervous system (Levine, 1992). However, and more akin with Cajal's theories on the neurotrophic activity of the Schwann cell (Azmitia, 2002), the theory gained momentum upon the discovery of the properties of the nerve growth factor - NGF (Levi-Montalcini, 1987). Then, its central tenet became that the survival of neurons during development of the nervous system was determined by the limited availability of trophic molecules delivered by target organs to the nerve terminals (Oppenheim, 1989).

\footnotetext{
\#These authors contributed equally to this work. *vmartins@ludwig.org.br
}

In parallel with the discoveries concerning a wide range of effects of NGF (Levi-Montalcini et al., 1996), work in the 1980s and 1990s greatly expanded the scope of the neurotrophic theory. Adding to the original emphasis on the role of individual target-derived neurotrophins (Thoenen et al., 1993), current neurotrophic theory allows for the operation of multiple neurotrophic systems upon single neurons (Davies, 1996), the production and physiological release of neurotrophic factors by glia (Sariola and Saarma, 2003), the role of afferent-derived molecules (Linden, 1994), trophic effects of both neurotransmitters and neuromodulators (Linden et al., 2005; Martins and Pearson, 2008), as well as cytokines (Krieglstein and Unsicker, 1996; Middleton et al., 2000) and hormones (Datson et al., 2008; Williams, 2008), and encompasses not only the survival but also the differentiation and functional integrity of components of the nervous system, among other complexities (Chao and Bothwell, 2002; Chao, 2003; Kalb, 2005; Levi-Montalcini and Calissano, 2006).

Neurotrophic interactions are based on cell-cell communication through either the release or the presentation at the cell surface, of specific molecules that bind to other molecules present in a target cell. The latter may be either the same cell, providing for autocrine effects, a neighboring cell or even reside at a distance, depending on both the neurotrophic factor and the structure and diffusion properties of the tissue environment. Both cell surface (Huang and Reichardt, 2003; Blochl and Blochl, 2007) and intracellular (Datson et al., 2008), including nuclear (Williams, 2008) receptors, serve as docking elements for the neurotrophic agents, and activate multiple signaling pathways leading to neurotrophic effects. Cell surface receptors constitute the majority of the targets of neurotrophic agents, and they can transfer signals through the plasma membrane either through their own intracellular domains, or via the activation of transmembrane partners (Yano and Chao, 2000; Runeberg-Roos and Saarma, 2007).

Evidence that the prion protein $\left(\mathrm{PrP}^{\mathrm{C}}\right)$ is involved in neurotrophic activity first appeared from studies in which the expression of $\mathrm{PrP}^{\mathrm{C}}$ prevented cell death triggered by serum deprivation of a hippocampal cell line (Kuwahara et al., 1999). It was subsequently shown that engagement of $\mathrm{PrPC}^{\mathrm{C}}$ with antibodies triggered cell signaling (Mouillet-Richard et al., 2000), and that interaction of $\mathrm{PrPC}^{\mathrm{C}}$ with a soluble binding partner induced neurotrophic-like effects mediated by the CAMP-protein kinase $A$ and Mitogen activated protein kinase (MAPK) pathways (Chiarini et al., 2002; Zanata et al., 2002; Lopes et al., 2005). Evidence that $\operatorname{PrP}^{\mathrm{C}}$ mediates neurotrophic interactions is now both abundant and compelling (e.g. (Nishimura et al., 2004; McLennan et al., 2004; Spudich et al., 2005; Coulpier et al., 2006; Rangel et al., 2007; Nazor et al., 2007; Weise et al., 2008; Rambold et al., 2008).

The hypothesis has been put forward that the prion protein functions as a dynamic cell surface platform for the assembly of signaling modules, based on which selective interactions with many ligands and transmembrane signaling pathways translate into wide-range consequences 
64 Martins et al.

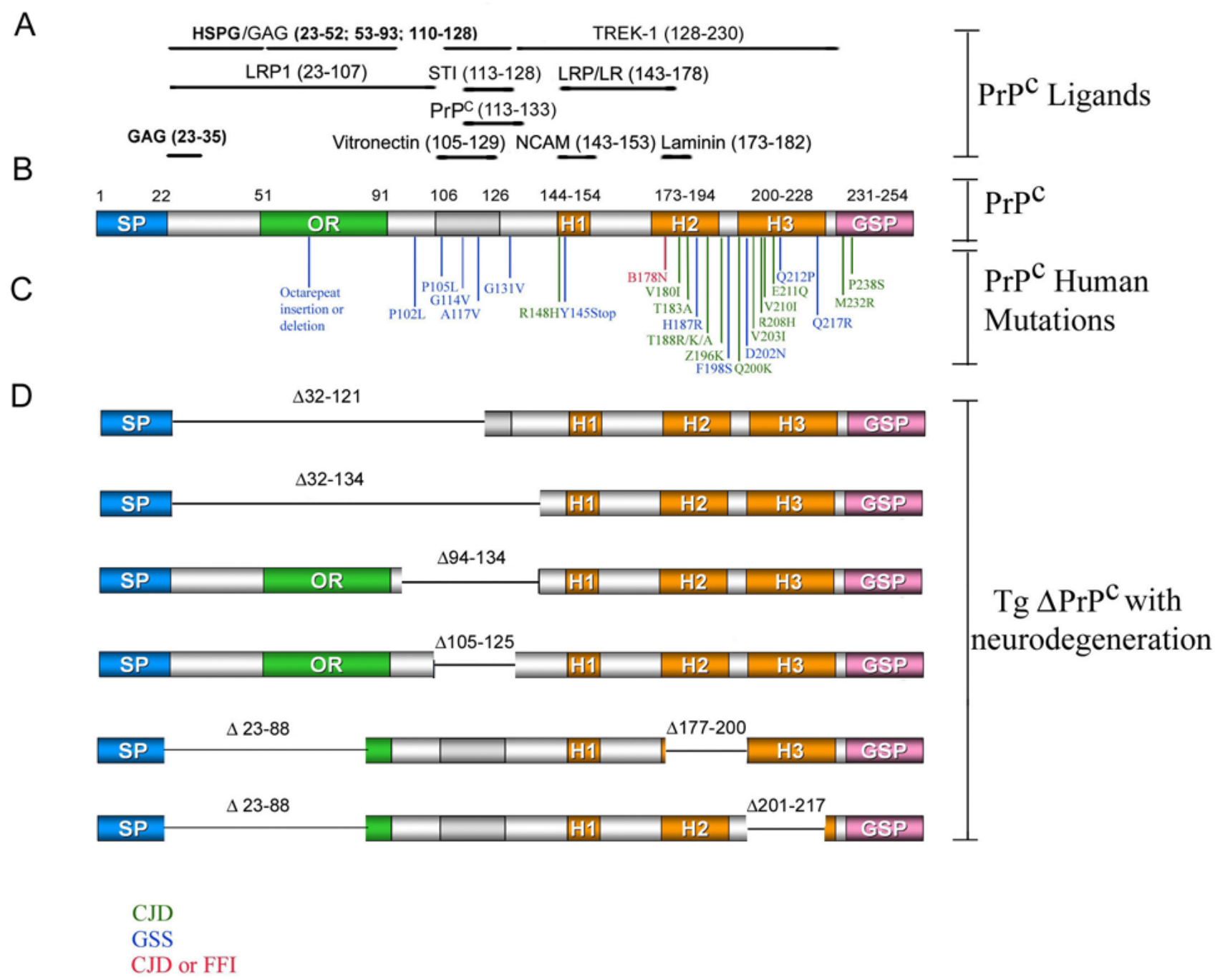

Figure 1. A schematic representation of $\mathrm{PrP}^{\mathrm{C}}$ with ligand binding sites, human mutations leading to prion diseases, and transgenic mouse models presenting neurodegeneration.

A) Mouse PrPC binding sites for ligands with neurotrophic activity. Numbers in parentheses indicate residue position. B) Schematic drawing of mouse PrPC. During the post-translational modification, the N-terminal signal peptide (SP) and GPI sequence (GPS) are cleaved and a GPI anchor is attached to the C-terminal. The flexible N-terminal portion contains octapeptide repeats $(\mathrm{OR})$ and a hydrophobic domain (dark grey). Orange boxes $(\mathrm{H} 1, \mathrm{H} 2$ and $\mathrm{H} 3$ ) represent regions of a-helical secondary structure. C) Mutations associated with inherited human prion diseases are indicated, CJD (green), GSS (Blue) and GSS/FFI (red). D) Deletions of $\operatorname{PrPC}^{\mathrm{C}}$ expression which cause neurodegeneration in transgenic mice, $\Delta$ numbers indicate the deleted domains.

upon both physiology and behavior (Linden et al., 2008). Thus, PrPC may scaffold various sets of extracellular and transmembrane molecules, providing for distinct signaling events, depending on the cell type, developmental stage, level of expression of both $\operatorname{PrPC}^{\mathrm{C}}$ and its partners, the availability of ligands in the immediate environment of the target cells, and endocytic trafficking (Linden et al., 2008). The current review focuses upon the role of $\operatorname{PrP}^{C}$ as a mediator of neurotrophic interactions, in the context of the hypothesis of loss-of-function components of prion diseases.

Following the cleavage of a signal peptide, the mammalian prion protein is produced mostly in the form of an N-glycosylated, GPI-anchored protein of 208-209 aa
(Riek et al., 1997; Lopez et al., 2000; Zahn et al., 2000; Hornemann et al., 2004; Calzolai et al., 2005; Lysek et al., 2005; Parkin et al., 2007), containing an $\mathrm{N}$-terminal flexible, random coil sequence that spans approximately half of its aminoacid residues, plus a C-terminal globular domain that constitutes the other half. The globular domain of human $\operatorname{PrP}^{\mathrm{C}}$ is arranged in $3 \mathrm{\alpha}$-helices corresponding to aas 144-154, 173-194 and 200-228, interspersed with an antiparallel $\beta$-pleated sheet formed by $\beta$-strands at residues $128-131$ and $161-164$. A single disulfide bond is formed by cysteine residues 179 and 214 . The $\mathrm{N}$-terminal residues 23-124 constitute the flexible tail, while residues 229-230 form a short flexible C-terminal domain (Zahn et al., 2000). Major structural features of $\mathrm{PrPC}^{\mathrm{C}}$ are remarkably preserved 
among both mammalian and non-mammalian species (Lopez et al., 2000; Hornemann et al., 2004; Calzolai et al., 2005; Lysek et al., 2005).

Full length $\mathrm{PrPC}^{\mathrm{C}}$ is found in non-, mono- or diglycosylated forms, corresponding to the variable occupancy of residues Asn181 and Asn197 in human PrPC - Asn180 and Asn196 in mice (Haraguchi et al., 1989). A rather large variety of $\mathrm{N}$-glycans were found attached to both fulllength and truncated $\mathrm{PrP}^{\mathrm{C}}$ (Rudd et al., 1999), which may be differentially distributed in various areas of the central nervous system (CNS) (DeArmond et al., 1999; Beringue et al., 2003). Although neither the attached N-glycans nor most of the GPI anchor appear to significantly affect major structural features of the prion protein (Hornemann et al., 2004), both may interfere upon the binding of physiological ligands, which, in turn, may be relevant for its neurotrophic properties (Linden et al., 2008).

\section{$\mathrm{PrP}^{\mathrm{C}}$ deletions in mice and mutations in humans: a tip for neurotrophic functions?}

Since the early 1990s, knockout constructions for PrP gene $\left(\mathrm{Prnp}^{0 / 0}\right.$ or $\left.\mathrm{Prnp}^{-/}\right)$have emerged as an attempt to elucidate the $\mathrm{PrP}^{\mathrm{C}}$ functions in vivo (Bueler et al., 1992; Manson et al., 1994). However, the first study in $\mathrm{PrP}^{\mathrm{C}}$-null mice did not reveal an obvious phenotype implying that $\mathrm{PrPC}^{\mathrm{C}}$ is either not essential for normal development, or could be compensated by other molecules (Bueler et al., 1992; Manson et al., 1994). However, when distinct features of these animals were investigated in further studies, subtle changes have been noticed in certain biological processes such as neurotransmission and synaptic plasticity (Collinge et al., 1994; Maglio et al., 2004; Prestori et al., 2008), hippocampal spatial memory (Criado et al., 2005) and aversive hippocampal memory in aged animals (Coitinho et al., 2003), circadian rhythms (Tobler et al., 1996; Tobler et al., 1997) and immune responses (de Almeida et al., 2005; Bainbridge and Walker, 2005). Remarkably, $\mathrm{PrP}^{\mathrm{C}}$-null mice also show higher sensitivity to various stress conditions which cause increased neuronal death (Walz et al., 1999; McLennan et al., 2004; Weise et al., 2004; Shyu et al., 2005; Weise et al., 2006; Rangel et al., 2007). Therefore, although compensatory mechanisms may balance the absence of $\mathrm{PrP}^{\mathrm{C}}$, they are not sufficient and the threshold for neuronal death is lower when $\mathrm{PrP}^{\mathrm{C}}$ is deleted.

Large and diverse phenotypic abnormalities were observed when $\mathrm{PrP}^{\mathrm{C}}$ deletion mutants were re-expressed in $\mathrm{Prnp}^{0 / 0}$ mice. $\mathrm{PrP}^{\mathrm{C}}$ mutants deleted either aas $32-121$, (PrP $\Delta 32-121)$ or 32-134 (PrP $\Delta 32-134)$, led to severe ataxia and apoptosis in the cerebellum (Shmerling et al., 1998). Severe demyelination and axon loss in both the spinal cord and cerebellar white matter were also observed in PrP $\Delta 32-134$ mice (Radovanovic et al., 2005) (Figure 1D). The leucodystrophy, but not the cerebellar granule cell degeneration, was rescued in these mice by oligodendrocytespecific expression of $\operatorname{PrP}^{C}$ (Radovanovic et al., 2005). On the other hand, neuron-specific expression of PrPC partially rescued cerebellar granule cell degeneration but not demyelination (Radovanovic et al., 2005). This indicates that these diseases are distinct, and that endogenous expression of $\mathrm{PrP}^{\mathrm{C}}$ in both neurons and glia was required for complete reversion of the degenerative phenotype.

Transgenic mice expressing truncated PrP $\Delta 94-134$, but not those expressing a smaller deletion $\operatorname{PrP} \Delta 114-121$, also showed extensive central and peripheral myelin degeneration and early ataxia, which progressed to spastic paraparesis and full paraplegia (Baumann et al., 2007). This lethal phenotype was not associated with the presence of pathological aggregates, altered $\mathrm{PrP}^{\mathrm{C}}$ glycosylation, subcellular mislocalization or inappropriate membrane topology (Baumann et al., 2007). Interestingly, the most prominent phenotype was observed in animals expressing an even smaller truncation, $\operatorname{PrP} \Delta 105-125$. These mice developed an extremely severe illness within two weeks of birth, with decreased body size and weight, immobility, impaired righting reflexes, myoclonus and tremor, and died within one month. Histopathology demonstrated cerebellar atrophy, severe loss of cerebellar granule cells, gliosis and astrocytic hypertrophy (Li et al., 2007). It is important to point that the degenerative phenotype observed in mice expressing PrP $\Delta 32-121, \operatorname{PrP} \Delta 32-134$, PrP $\Delta 94-134$ or PrP $\Delta 105-125$ was rescued by introducing the wild-type Prnp gene (Shmerling et al., 1998; Baumann et al., 2007; Li et al., 2007).

These deleted regions likely contain functional $\operatorname{PrPC}$ domains relevant for trophic interactions. They lay within the $\mathrm{N}$-terminal and hidrophobic regions, which are the less structured domains and therefore more accessible regions. In fact, this is the interface for $\mathrm{PrP}^{\mathrm{C}}$ dimerization (Rambold et al., 2008) and the region where most of the binding sites for $\mathrm{PrPC}^{\mathrm{C}}$ ligands such as Heparan Sulphate Proteoglicans (HSPG), vitronectin, low-density lipoprotein receptor related protein 1 (LRP1) and Stress Inducible Protein 1 (STI1) were identified (Figure 1A).

Transgenic mice expressing truncated molecules at the C-terminal of $\mathrm{PrP}^{\mathrm{C}}$, also presented an altered phenotype. The expression of truncated $\mathrm{PrP}^{\mathrm{C}}$ molecules, PrP $\Delta 177-200$ or PrP $\Delta 201-217$, associated with another deletion at aas 23 to 88 , which is by itself innocuous, caused a neuronal storage disease associated with neurodegeneration and signals of cerebellar disorder (Muramoto et al., 1997). Both deletions caused $\mathrm{PrP}^{\mathrm{C}}$ accumulation within cytoplasmatic inclusion bodies in enlarged neurons. Relative smaller number of axons in the white matter tracks were observed in PrP $\Delta 177-200$ while PrP $\Delta$ 201-217 animals presented extensive nerve cells loss in the CA1 region of the hippocampus (Muramoto et al., 1997) (Figure 1D).

The $\mathrm{PrPC}^{\mathrm{C}}$ ligands at the C-terminal domain of $\mathrm{PrPC}^{\mathrm{C}}$ characterized until recently are laminin, $37 \mathrm{kDa}$ Laminin Receptor Precursor/ 67 kDa Laminin Receptor (37LRP/67LR), and the $\mathrm{K}^{+}$channel, TREK1 (Figure 1A). All these ligands present neurotrophic properties, and particularly the association of laminin with $\mathrm{PrPC}^{\mathrm{C}}$ allows for neuritogenesis and maintenance of growth cones (see below).

In turn, a large spectrum of clinical symptoms and pathological features are found in patients presenting genetic prion diseases. A series of at least 55 pathogenic mutations are distributed along the $\operatorname{PrP}^{C}$ sequence, and respond for 3 distinct illnesses: Creutzfeldt - Jakob disease (CJD), Gerstmann-Sträussler-Scheinker (GSS) Syndrome, and Fatal Familial Insomnia (FFI) (Figure 1C).

Two octapeptide deletions and 29 insertions were described in the octarepeat region, with the former being associated with a CJD phenotype and later often linked with GSS (Kong Q et al., 2003). Seven point mutations are found in the N-terminal domain and Helix $1(\mathrm{H} 1)$ of $\mathrm{PrP}^{\mathrm{C}}$ and 6 of 
them cause GSS (Figure 1C). On the other hand, 11 out of 17 mutations described in the C-terminal domain of $\mathrm{PrPC}^{\mathrm{C}}$ cause CJD and most of them are clustered in helices 2 and 3 ( $\mathrm{H} 2$ and H3) (reviewed by Kong et al., 2003; Rodriguez et al., 2005; Ye et al., 2008). Thus, there is a preferential cluster of GSS phenotypes associated with the N-terminal and $\mathrm{H} 1$ regions and a preferential CJD phenotype linked to the C-terminal domain of $\mathrm{PrP}^{\mathrm{C}}$.

The human $\mathrm{PrP}^{\mathrm{C}}$ domain comprehending aas 95 to 135 (equivalent to mouse 94 to 134 ) presents 5 point mutations (P102L, P105L, G114V, A117V and G131V) all of each associated with GSS. This is exactly the PrPC domain the deletion of which causes neurodegeneration in mice, as discussed above. Remarkably, although brain homogenates obtained from GSS patient with P102L mutation induced spongiform encephalopathy in recipient animals (Masters et al., 1981), mice overexpressing the transgene P101L (corresponding to the human 102) showed spontaneous neurodegeneration without any detectable protease-resistant PrPSc (Telling et al., 1996). In addition, the mutation A117V which appears to induce the formation of a transmembrane form (Ctm) of $\mathrm{PrPC}^{\mathrm{C}}$, produced neurodegenerative changes in mice but does not cause either $\mathrm{PrPSc}^{\mathrm{Sc}}$ deposition or infection in rodents (Hegde et al., 1998). Conversely, the expression of the CJD-linked mutations T183A (DeArmond et al., 1997) or E199K (human E200K) (Telling et al., 1996) in PrPnull mice did not cause any pathological signals.

In cell cultures, the $\mathrm{PrP}^{\mathrm{C}}$ hydrophobic domain 113-123 was required for the stress-protective activity of $\mathrm{PrPC}^{\mathrm{C}}$ (Rambold et al., 2008). In addition, some PrPC mutants associated to genetic prion diseases and presenting codon $129 \mathrm{M}$ are unable (D178, V181I, E196K, V210I, M232R and P238S) or only partially effective (R208H, E211Q) to protect against Bax-mediated cell death (Jodoin et al., 2007). Interestingly, the presence of $129 \mathrm{~V}$ renders mutated proteins into less active forms (A117V, V203I and T188A) or inactive (E200K, R208H, E211Q) for this phenptype (Jodoin et al., 2007).

The truncation of specific $\mathrm{PrP}^{\mathrm{C}}$ domains in transgenic mice or the presence of PRNP mutations associated with human genetic prion diseases may alter the recruitment of specific proteins to a $\mathrm{PrP}^{\mathrm{C}}$-based multi-component complex (Martins et al., 2002; Linden et al., 2008) in particular those already known to interact with specific $\mathrm{PrPC}^{\mathrm{C}}$ domains and promote neurotrophic functions. In addition, the composition of these complexes may vary among neurons and glial cells which may explain, at least in part, the diverse degenerative phenotypes observed in transgenic mice and in patients expressing mutated $\mathrm{PrP}^{\mathrm{C}}$.

\section{The PrPC ligands mediating neurotrophic activity}

Several dozen proteins have been described to bind PrPC in various cellular compartments, but in most cases there is still no known associated biological function for these interactions (Linden et al., 2008). PrPC is normally localized at the cell surface and traffics along the endocytic pathway (Prado et al., 2004), consistent with the idea that its association with other proteins in these compartments may be relevant for its neurotrophic activity.

Extracellular matrix (ECM) components, as well as their receptors at the cell surface, are known to create a milieu necessary for survival and differentiation in the developing nervous system (Pires Neto et al., 1999; De and GeorgesLabouesse, 2000) and in the remodeling of adult brain in both normal (Grimpe and Silver, 2002) and pathological conditions (Rauch, 2004; Theodosis et al., 2004). PrPC is able to associate with ECM proteins such as laminin (Graner et al., 2000a; Graner et al., 2000b) and vitronectin, but not to fibronectin or collagen (Hajj et al., 2007). $\mathrm{PrP}^{\mathrm{C}}$ also binds to ECM glycosaminoglycans such as heparin and heparan sulfate (Warner et al., 2002) and to ECM receptors such as the $37 \mathrm{kDa}$ Laminin Receptor Precursor/ $67 \mathrm{kDa}$ Laminin Receptor (37LRP/67LR) (Rieger et al., 1997).

Laminins are large (400-900 kDa) extracellular heterotrimeric glycoproteins composed of various combinations of $\alpha, \beta$, and $\gamma$ chains. To date, five $\alpha$, four $\beta$, and three $\gamma$ chains have been identified, which may combine into sixteen known forms of laminins in mammals. The individual chains present diverse biological active domains and interact with a large number of receptors, such as at least eight different integrins, 37LRP/67LR, dystroglycan, $67 \mathrm{kDa}$ elastin-laminin receptor, galactoside-binding lectin, galactosyltransferase, heparan sulfate proteoglycans and immunoglobulin-related basal cell adhesion molecule (Tzu and Marinkovich, 2008). These varied interactions are crucial to promote the diverse biological functions attributed to laminin in distinct cell types, particularly in the nervous system (Colognato and Yurchenco, 2000). For example, laminin is one of the most important ECM proteins responsible for axonal growth (Luckenbill-Edds, 1997). In addition, defects in both the peripheral and central nervous system frequently accompany mutations in laminin isoforms. Also, the loss of interneuronal laminin in the hippocampus due to proteolysis induced by excitotoxicity, leads to neuronal death (Colognato et al., 2005).

$\mathrm{PrP}^{\mathrm{C}}$ binds to a laminin domain at the $\mathrm{y}-1$ chain (Graner et al., 2000a; Graner et al., 2000b), a region previously demonstrated to promote neuritogenesis (Liesi et al., 1989). The laminin binding site resides within amino acids 173-182 of the $\mathrm{PrP}^{\mathrm{C}}$ molecule (Coitinho et al., 2006). Using primary hippocampal neuron cultures from either wild-type or PrPC. null mice, it was shown that the interaction of $\operatorname{PrP}^{C}$ with the laminin $y-1$ chain induces neuritogenesis (Graner et al., 2000a). Inactivation of $\operatorname{PrPC}^{\mathrm{C}}$ by chromophore-assisted laser inactivation (CALI) in PC-12 cells also impaired neurite extension induced by laminin. Furthermore, retraction of growth cones was observed when micro-CALI was used to inactivate $\mathrm{PrPC}^{\mathrm{C}}$ in these structures (Graner et al., 2000b).

The importance of the interaction of $\mathrm{PrP}^{\mathrm{C}}$ and laminin was also demonstrated in vivo. Antibodies against either the entire $\mathrm{PrPC}^{\mathrm{C}}$ and laminin molecules, or against peptides representing the binding sites either in $\mathrm{PrP}^{\mathrm{C}}$ or in laminin $\mathrm{Y}-1$ chain, blocked memory consolidation when infused in the rat hippocampus. In addition, the $\mathrm{y}-1$ chain peptide competed with antibodies against the $\operatorname{PrPC}^{\mathrm{C}} 170-183$ peptide, and reversed the latter's inhibitory activity upon memory consolidation (Coitinho et al., 2006). Thus, PrPC_ aminin interaction in the hippocampus is associated with neuritogenesis, with an impact upon neuronal plasticity and memory consolidation.

$\mathrm{PrP}^{\mathrm{C}}$ also interacts with $37 \mathrm{LRP} / 67 \mathrm{LR}$, one of the first ligands of $\mathrm{PrPC}^{\mathrm{C}}$ identified by using a two-hybrid system (Rieger et al., 1997). The 37LRP/67 LR is a membrane associated protein, first discovered by laminin-sepharose affinity chromatography. At first, 37LRP/67LR interaction 
with laminin was considered to be simply adhesive. However, it is now clear that activation of the 37LRP/67LR induces dynamic events (increased filopodia, directional motility and modulation of gene expression), as a consequence of hitherto poorly understood signal transduction. In addition to direct interactions with laminin, it has been proposed that the 67LR facilitates interactions between laminin and integrins (Nelson et al., 2008).

The interaction between $\mathrm{PrP}^{\mathrm{C}}$ and the 37LRP/67LR was confirmed in mammalian cells, where it was shown that 37LRP/67LR co-localizes with $\mathrm{PrP}^{\mathrm{C}}$ at the cell surface. Recombinant or purified $\mathrm{PrP}^{\mathrm{C}}$ bind $37 \mathrm{kDa}$ LRP/ 67kDa LR at the cell surface, where the latter mediates the internalization of exogenous added PrPC (Gauczynski et al., 2001). It should be noted, however, that this exogenous added $\mathrm{PrPC}^{\mathrm{C}}$ lacks the localization in rafts and is of course not GPI-anchored at the membrane. The binding residues for $37 \mathrm{kDa}$ LRP/ $67 \mathrm{kDa}$ LR have been identified between amino acids 144-179 in $\mathrm{PrP}^{\mathrm{C}}$ (Hundt et al., 2001), which partially overlaps the binding site for laminin itself (Coitinho et al., 2006). Thus, it is likely that interaction of $\mathrm{PrP}^{\mathrm{C}}$ either with the 37LRP/ 67LR or laminin may be mutually exclusive at this $\operatorname{PrPC}^{\mathrm{C}}$ domain. Although this competitive interaction has yet to be tested, such an overlap, together with the coincidence of binding sites in 37LRP/ 67LR for both laminin and $\mathrm{PrPC}^{\mathrm{C}}$ (Rieger et al, 1999), should have important consequences for the effects of $\mathrm{PrP}^{\mathrm{C}}$ upon neurite growth and differentiation.

Binding of 37LRP/67LR to an additional binding site at $\mathrm{PrP}^{\mathrm{C}}$ amino acids 53 to 93 is mediated by the presence of heparan sulfate proteoglycans at 37LRP/67LR. Interestingly, the 37LRP/67LR domain which contains heparan sulfate proteoglycans maps to between amino acids $101-160$ or 180-295 (Hundt et al., 2001), the latter of which straddles a laminin binding region (205-229) (Nelson et al., 2008). Indeed, two out of three laminin binding sites at the 37LRP/67LR may compete by the latter's interaction with $\operatorname{PrPC}$.

Remarkably, barring steric hindrance constrains, laminin may be able to simultaneous bind the 37LRP/67LR (using its third available binding site located within the cysteinerich EGF-like repeat in the $\beta 1$ subunit) (Nelson et al., 2008), $\mathrm{PrP}^{\mathrm{C}}$ (at the C-terminal portion of the $\mathrm{Y} 1$ chain), as well as other receptors, such as integrins (most of which bind to the a chain of laminin) (Tzu et al., 2008). These multiple interactions would lead to the assembly of a molecular cluster of cell membrane receptors, which may promote neurotrophic signaling by both integrin-mediated signal transduction, as well as through signals initiated by activation of $\mathrm{PrP}^{\mathrm{C}}$ by laminin, followed by its possible internalization mediated by the 37LRP/67LR (Figure 2A). This is but one of the multicomponent signaling modules that may be assembled through molecular interactions mediated by the prion protein (Martins et al., 2002; Linden et al., 2008).

Interaction of $\mathrm{PrP}^{\mathrm{C}}$ with glycosaminoglycans, particularly heparan sulfate, has been extensively documented (Priola and Caughey, 1994). In addition, in vitro binding studies demonstrated that $\mathrm{PrPC}^{\mathrm{C}}$ directly interacts with heparan sulfate through domains 23-52, 53-93, and 110-128 (Warner et al., 2002). Although no functional consequence of this interaction has been addressed so far, it may have important consequences especially for the binding and internalization of the 37LRP/ 67LR.
The $\mathrm{PrP}^{\mathrm{C}}$ role as an $\mathrm{ECM}$ receptor/co-receptor is not limited to laminin. PrPC also binds another ECM protein, vitronectin (Vn), through amino acids 106-116 (Hajj et al., 2007). This $\mathrm{PrP}^{\mathrm{C}}-\mathrm{Vn}$ interaction is important for the growth of axons in dorsal root ganglia during embryogenesis (Hajj et al., 2007) (Figure 2A). Interestingly, vitronectin has been described to have important roles in motor neuron differentiation in association with the morphogen Sonic Hedgehog (Pons and Marti, 2000; Pons et al., 2001). Also during development of the cerebellum, the migration of granular neurons is regulated by an ECM transition. When cells are in the external granule cell layer, the most predominant ECM molecule is laminin, which stimulates granule cells to proliferate. When cells start to migrate to the internal granule cell layer, they move towards an ECM region rich in vitronectin. Cells that reach vitronectin stop proliferating and differentiate, forming the layers of the fully differentiated cerebellum (Pons et al., 2001). Since PrPC binds both laminin and vitronectin it may be involved in the development of the cerebellum, by regulating the precise moment of each association and thus influencing the fate of the cells.

Remarkably, knocking down $\operatorname{PrP}^{\mathrm{C}}$ in cerebellar neural circuits and in particular on granule cells, compromises the function of these cells causing behavioral alterations such as low performance in rotarod and runway tests. It was demonstrated that cerebellar granule cells from wild-type mice stop their division by the second post-natal week, as expected, while $\mathrm{PrP}^{\mathrm{C}}$-null granule cells divide until post-natal week three. With older age, these differences disappear indicating that the absence of $\operatorname{PrP}^{\mathrm{C}}$ can be compensated during the development (Prestori et al., 2008).

Perhaps the most extensively studied $\mathrm{PrP}^{\mathrm{C}}$-binding protein, so far, is Stress Inducible Protein 1 (STI1). Interaction of $\mathrm{PrP}^{\mathrm{C}}$ with a $66 \mathrm{kDa}$ protein was discovered in 1997 , and the latter was proposed as a $\mathrm{PrP}^{\mathrm{C}}$ receptor, which might be responsible for mediating $\mathrm{PrP}^{\mathrm{C}}$ internalization and inhibiting the toxicity of the $\mathrm{PrP}^{\mathrm{C}}$ peptide 106-126 (Martins et al., 1997). It was subsequently found that the interaction between the $66 \mathrm{kDa}$ protein and $\mathrm{PrP}^{\mathrm{C}}$ triggered protection against apoptosis in an in vitro retina model (Chiarini et al., 2002). Notwithstanding the lack of evidence for its functioning as a $\mathrm{PrP}^{\mathrm{C}}$ receptor (Zanata et al., 2002), the role of STI1 as an important inducer of $\mathrm{PrP}^{\mathrm{C}}$-mediated neurotrophic effects was further supported by the demonstration that their binding promoted both protection against neuronal death as well as neuritogenesis, through the PKA and ERK1/2 signaling pathways, respectively (Lopes et al., 2005) (Figure 2B).

Recent work in astrocytes has shown that STI1 is a secreted $\mathrm{PrP}^{\mathrm{C}}$ ligand. STI1 is released by cultured astrocytes in large amounts by still unknown mechanisms, and interacts with neuronal $\mathrm{PrPC}^{\mathrm{C}}$, promoting protection against cell death (Lima et al., 2007). Effects of STI1 in vivo have also been demonstrated. Experiments with rats in an inhibitory avoidance task demonstrated that antibodies against STI1 and $\mathrm{PrP}^{\mathrm{C}}$, when injected directly into the hippocampus, impair memory formation and consolidation. Remarkably, the STI1 peptide that represents the PrPC binding site improves memory formation and consolidation (Coitinho et al., 2007). It is, however, still unknown whether the effects upon memory are related to neurotrophic effects of the interaction of $\mathrm{STI} 1$ with $\mathrm{PrPC}^{\mathrm{C}}$. 
A

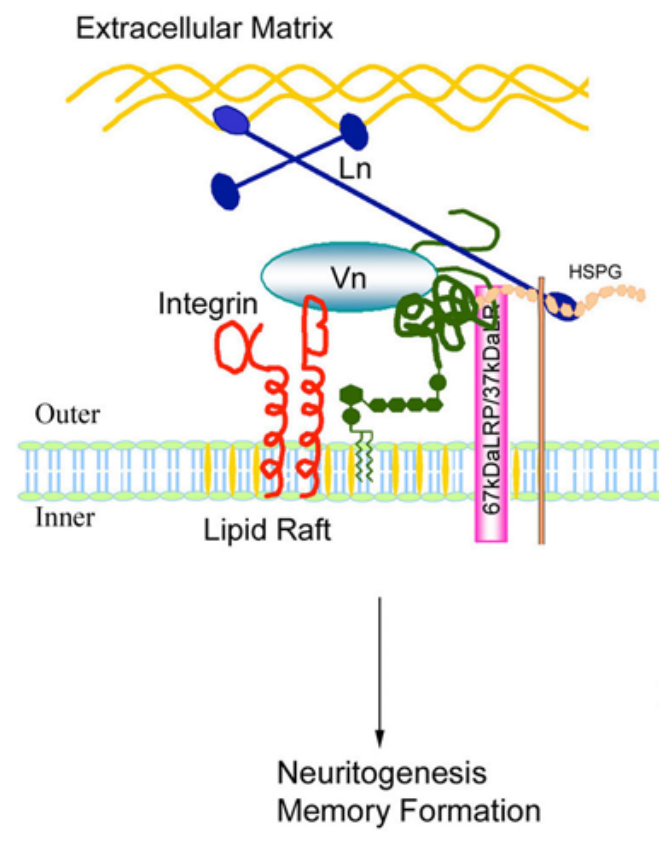

B

C

Figure 2. The $\operatorname{PrP}^{\mathrm{C}}$ ligands mediating neurotrophic activity.

A) $\operatorname{PrP}^{\mathrm{C}}$ directly interacts with the ECM proteins: Laminin (Ln) and Vitronectin $(\mathrm{Vn})$, and with the laminin receptor (37LRP/67LR), possibly forming a large complex involved in neuritogenesis and memory formation. Interaction of the laminin receptor with $\mathrm{PrP}^{\mathrm{C}}$ is also mediated by Heparan Sulfate Proteoglycans (HSPG). Integrins are ECM receptors, and may also take part in this complex. B) $\operatorname{PrP}^{\mathrm{C}}$ interacts with the secreted Stress Inducible Protein 1 (STI1), which mediates neuroprotection and neuritogenesis through independent signaling pathways (PKA and ERK1/2). C) NCAM is a transmembrane protein that interacts with $\mathrm{PrP}^{\mathrm{C}}$ either in cis or in trans, and promotes neuritogenesis through the activation of Fyn kinase.

PrPC modulates expression and/or activity of transmembrane receptors associated with neurotrophic activities. Since so many ligands have been ascribed to $\mathrm{PrP}^{\mathrm{C}}$, the fundamental question remaining about $\operatorname{PrP}^{\mathrm{C}}$ is how the signal is transduced through the membrane. $\mathrm{PrPC}^{\mathrm{C}}$ is a GPI-linked protein known to be preferentially localized in membrane domains enriched in sphingolipids and cholesterol (lipid rafts) (Fivaz et al., 2002). These raft domains contain several molecules which recruit specialized proteins for intracellular signaling (Gorodinsky and Harris, 1995) and it is possible that $\mathrm{PrPC}^{\mathrm{C}}$ can modulate the activity of these proteins by either direct or indirect interaction.

In fact, several transmembrane proteins with neurotrophic activities were shown to be modulated by $\operatorname{PrP}^{\mathrm{C}}$, leading to the activation or inhibition of intracellular signal pathways. These proteins include the neural cell adhesion molecule (NCAM) (Santuccione et al., 2005), integrins (Hajj et al., 2007), G protein coupled receptors (Kristensson et al., 1993; Wong et al., 1996; Mouillet-Richard et al., 2000; Brini et al., 2005) and membrane ion channels (Whatley et al., 1995; Colling et al., 1996; Herms et al., 2001; Azzalin et al., 2006; Khosravani et al., 2008).

NCAM plays crucial roles in brain development, synaptic plasticity and regeneration and is considered an inducer of complex intracellular signaling cascades in response to extracellular cues triggered by either homophilic or heterophilic binding (Ditlevsen et al., 2008). PrPC -NCAM interaction is direct (Schmitt-Ulms et al., 2001) and occurs in either cis or trans, i.e. both molecules in the same cell or in distinct cells, respectively. This interaction takes place in raft microdomains, where NCAM uses its $\mathrm{PrPC}^{\mathrm{C}}$-guided enrichment in lipid rafts to activate p59fyn kinase and inducing neuritogenesis (Santuccione et al., 2005) (Figure $2 \mathrm{C}$ ). These data are especially interesting, since it has been demonstrated that Fyn kinase pathway is the most relevant for NCAM-induced neurite outgrowth and synaptic functions (Ditlevsen et al., 2008). On the other hand, NCAM-induced signaling also engages other signaling molecules, such as focal adhesion kinase, growth-associated protein-43, the mitogen-activated protein kinase (MAPK), intracellular $\mathrm{Ca}^{2+}$, and protein kinases A, C, and G (reviewed by (Ditlevsen et al., 2008). In fact, it has been recently demonstrated that $\mathrm{PrPC}^{\mathrm{C}}$ accumulates is focal adhesions, modulationg cellsubstrate interactions both in cells from mammals and Drosophila. When PrPC is highly expressed it modulates cell spreading and filopodia formation while in low levels of $\mathrm{PrPC}^{\mathrm{C}}$ lamellipodia is more abundant (Schrock et al., 2009).

The major role of $\operatorname{PrP}^{C}$ in cell adhesion and cell-cell communication has also been elegantly demonstrated in zebrafish which presents two $\operatorname{PrPC}^{\mathrm{C}}$ gene orthologues (PrP1 and PrP2). Deletion of PrP1 caused impairment of embryonic cell adhesion and arrested gastrulation (MalagaTrillo et al., 2009) while PrP2 removal affects latter stages of neuronal development possibly affecting proliferation and 


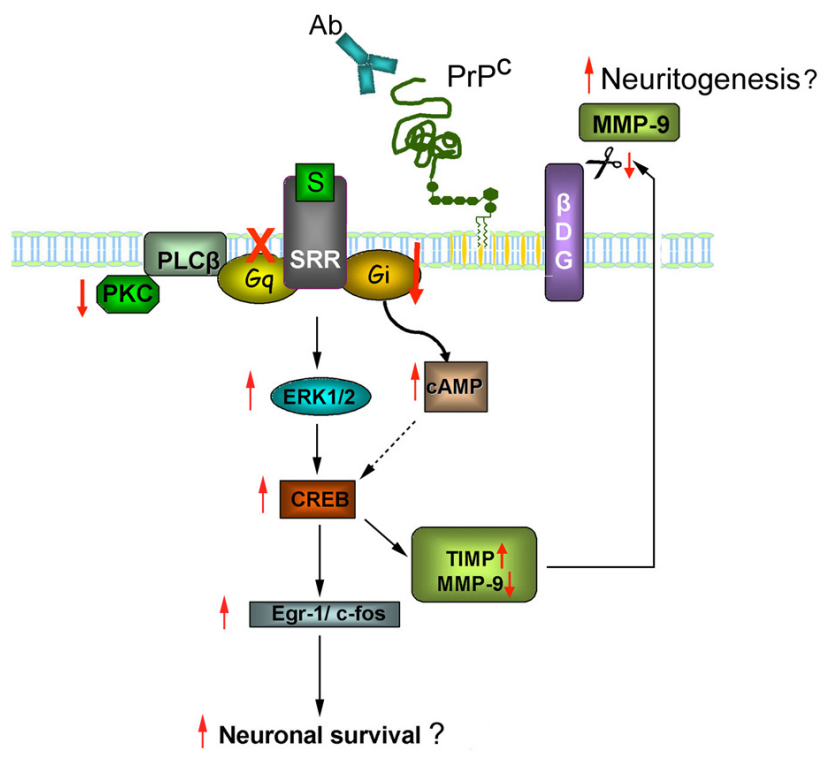

Figure 3. Engagement of $\mathrm{PrP}^{\mathrm{C}}$ with specific antibodies modulates signal transduction by altering the activity of $G$ protein-coupled serotonergic receptor. The serotonergic receptor (SRR) in the cell membrane is associated with a calcium stimulatory $\mathrm{G}$ protein $(\mathrm{Gq})$, to the Phospholipase $C \beta$ (PLC $\beta$ and with a cAMP inhibitory $G$ protein $(\mathrm{Gi})$. This complex responds to serotonin (S) by activating PKC, modulating the levels of CAMP/ERK1/2 (Extracellular Signal-Regulated Kinases 1/2) and CREB (CAMP response element binding protein) pathways. $\mathrm{PrP}^{\mathrm{C}}$ binding to specific antibodies $(A b)$ impaired PLC $\beta / P K C$ signaling pathway and partially blocked the reduction of CAMP, up modulates ERK, CREB and Egr-1/c-Fos. These factors may contribute to neuronal survival. On the other hand, up modulation of CREB increases the transcription of TIMP-1 and decreases MMP-9 levels. MMP-9 is a secreted metalloproteinase that cleaves $\beta$-dystroglycan (BDG) reducing cell-matrix adhesion. Upon $\operatorname{PrP}^{\mathrm{C}}$ ligation, MMP9 levels are diminished and $\beta$-dystroglycan interaction with the extracellular matrix is stabilized, what may increase neuritogenesis.

differentiation of developing neurons (Malaga-Trillo et al., 2009 and unpublished results). The alterations related to PrP1 are caused by deficient cell movements modulated by E-cadherin-based adhesion and signaling which are conserved across vertebrates.

As described above $\mathrm{PrPC}^{\mathrm{C}}$ is able to interact with vitronectin. The vitronectin peptide which represents the $\mathrm{PrP}^{\mathrm{C}}$ binding site promotes axonal growth in wild-type but not in $\mathrm{PrP}^{\mathrm{C}}$-null neurons. Vitronectin, on the other hand, supports axonal growth in both wild-type and $\mathrm{PrP}^{\mathrm{C}}$-null neurons, suggesting that other vitronectin ligands can compensate for the absence of $\mathrm{PrP}^{\mathrm{C}}$. In fact, the conduction of functional assays showed that neurons derived from two different $\mathrm{PrP}^{\mathrm{C}}$-null mouse strains presented higher activity of the integrin $\alpha v \beta 3$ (Hajj et al., 2007), a classical vitronectin transmembrane receptor. Although, a direct interaction of $\alpha v \beta 3$ with $\mathrm{PrP}^{\mathrm{C}}$ has never been demonstrated, $\beta 3$ integrin immunoprecipitates with $\operatorname{PrPC}^{C}$ (Hajj $G$ and Martins VR, unpublished results) and $\beta 1$ integrin is engaged by antibody crosslinking-mediated neuritogenesis (Pantera et al., 2009), indicating that they can associate in the same protein complex (Figure 2A).

Integrins are a large group of heterodimeric surface membrane receptors widely expressed in the nervous system and have been shown to have diverse roles in axon extension, neural development and, in addition, they are key regulators of synaptic plasticity involved in memory and learning in the adult nervous system (reviewed by (Clegg et al., 2003). The negative control of integrin activity by $\mathrm{PrP}^{\mathrm{C}}$ may represent an important regulation of neurotrophic functions.

In the neuroectodermal progenitor $1 \mathrm{C} 11$ cell line, that can be differentiated into either serotonergic $\left(1 \mathrm{C} 11^{5-\mathrm{HT}}\right)$ or noradrenergic $\left(1 \mathrm{C} 11^{\mathrm{NE}}\right)$ phenotype, the engagement of $\mathrm{PrPC}$ with antibodies had a high impact on signal transduction (Mouillet-Richard et al., 2000). This effect was restricted to cell processes and most likely on varicosities of the neurites (Mouillet-Richard et al., 2000). PrPC engagement with G-protein coupled serotonergic receptors (GPCR) 5-HT, 5HT2A, 5HT1B/D and 5-HT2B simultaneously with their stimulation by agonists, altered the intensities and/or dynamics of $\mathrm{G}$ protein activation (Mouillet-Richard et al., 2005). In particular, $\mathrm{PrP}^{\mathrm{C}}$ binding with antibodies impaired phospholipase $C \beta$ (PLC $\beta$ ) activation by $5-\mathrm{HT} 2 \mathrm{~A}$ receptors, partially blocked the reduction of cAMP promoted by agonist binding to $5-\mathrm{HT} 1 \mathrm{~B} / \mathrm{D}$ and potentiated the Phospholipase A2 response through 5-HT2A (Mouillet-Richard et al., 2005). In addition, the same procedure triggered transduction cascades controlling the cellular redox state and the ERK1/2 kinases (Mouillet-Richard et al., 2007), leading to CREB activation followed by transcription of Egr-1 and c-fos. These factors have been previouly associated with the control of neuronal survival (Zhang et al., 2002; Thiel and Cibelli, 2002). On the other hand, the transcription of the metalloproteinase TIMP-1 was enhanced by CREB while the transcription of MMP-9 was reduced, decreasing the processing of $\beta$-dystroglycan. Since MMP-9 process laminin, which is also a ligand for $\beta$-dystroglycan, it has been suggested that the $\mathrm{PrP}^{\mathrm{C}}$-mediated control of MMP-9 stabilizes the interaction between $\operatorname{PrP}^{\mathrm{C}}$ and its cell/ECM partners, and may potentiate synaptic efficacy (Pradines et al., 2008) (Figure 3).

The transfection of the $\mathrm{PrPC}^{\mathrm{C}}$ gene into $\mathrm{CHO}$ cells affects intracellular calcium dynamics following activation of purinergic receptors (P2Y). In transfected cells treated with ATP, $\mathrm{Ca}^{2+}$ mobilization from endoplasmic reticulum and $\mathrm{Ca}^{2+}$ uptake by mitochondria were lower than in non-transfected cells (Brini et al., 2005). These alterations are known to reduce cellular sensitivity to $\mathrm{Ca}^{2+}$-mediated apoptosis and therefore, are cytoprotective (Giacomello et al., 2007; Marchi et al., 2008). In addition, the expression of $\mathrm{PrPC}^{\mathrm{C}}$ in $\mathrm{CHO}$ cells also increased the the $\mathrm{Ca}^{2+}$ influx through the plasma membrane after ATP treatment (Brini et al., 2005). It was speculated that the latter effect was mediated by PrPC activation of store operated calcium channels (SOCCs) (Brini et al., 2005). These channels are functionally coupled with the activation of adenyl cyclase (Fagan et al., 2000) which has been associated with $\mathrm{PrP}^{\mathrm{C}}$-mediated neuronal survival (Chiarini et al., 2002; Lopes et al., 2005) (Figure 4). Whether $\mathrm{Ca}^{2+}$ hadling of the main intracellular stores and entry from extracellular space depend on the direct interaction of $\mathrm{PrP}^{\mathrm{C}}$ with $\mathrm{P} 2 \mathrm{Y}$ receptors or SOCCs is still unknown. 


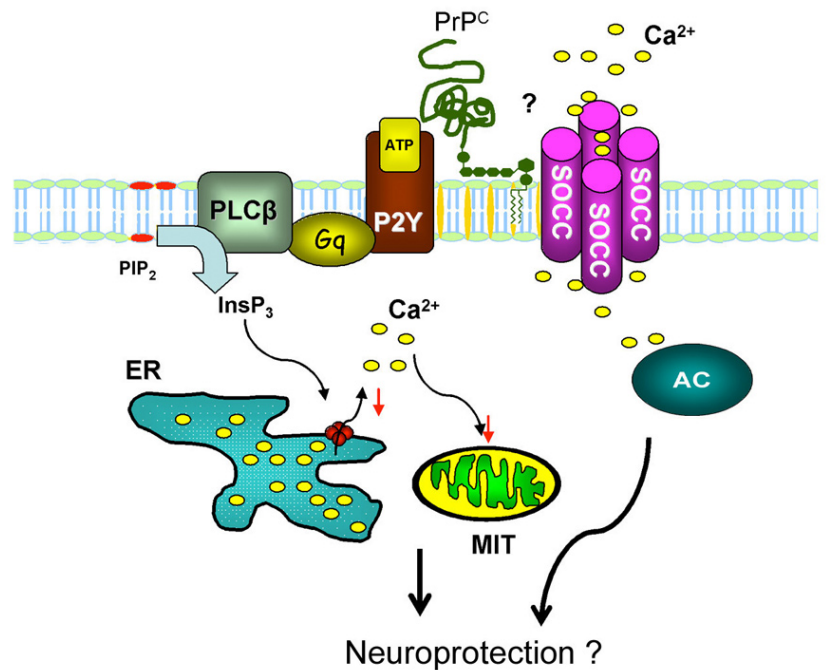

Figure 4. Expression of $\mathrm{PrP}^{\mathrm{C}}$ modulates intracellular $\mathrm{Ca}^{2+}$ homeostasis and signaling transduction through $\mathrm{G}$ proteincoupled purinergic receptors. The purinergic receptors $(\mathrm{P} 2 \mathrm{Y})$ are transmembrane proteins coupled to calcium stimulatory $\mathrm{G}$ protein $(\mathrm{Gq})$ and to phospholipase $C \beta$ (PLC $\beta)$. $\mathrm{P} 2 \mathrm{Y}$ receptors are activated by ATP, promoting cleavage of phosphatidylinositol-bisphosphate (PIP2) into Inositol-3Phosphate (InsP3) by the PLC $\beta$. InsP3 promotes a calcium release from the endoplasmic reticulum (ER), and released calcium can be sequestered by the mitochondria, leading to cell death. The expression of $\mathrm{PrP}^{\mathrm{C}}$ leads to a reduction of $\mathrm{Ca}^{2+}$ mobilization from the $\mathrm{ER}$ and $\mathrm{Ca}^{2+}$ uptake by the mitochondria what can contribute to neuronal protection. In contrast, there is an increasing of calcium influx through the plasma membrane, probably by the activation of Store Operated Calcium Channels (SOCCs) and increase of the activity of adenylate cyclase. The latter has been associated with $\mathrm{PrP}^{\mathrm{C}}$-mediated neuroprotection.

Prion infection reduced the effect of bradykinin on the increase of intracellular $\mathrm{Ca}^{2+}$ (Kristensson et al., 1993). This alteration occurs by a reduced affinity of BK for its receptor and also by a modification of lipid composition in the plasma membrane with the diminished availability of phosphatidylinositol-bisphosphate (PIP2). Bradykinin is a 9-amino acid peptide with a wide range of biological actions mediated through B1 and B2 subtypes of G-protein-coupled receptors (reviewed by (Calixto et al., 2004). Activation of these receptors induces a transient increase in the cytosolic concentration of calcium caused by both its mobilization from intracellular stores and influx from extracellular environment (Kristensson et al., 1993 ; Martins et al., 2005). This has been associated with neuroprotection after ischemia (Ping et al., 2005; Yan-Feng et al., 2008; Danielisova et al., 2008). Whether $\operatorname{PrP}^{C}$ modulates the activity of bradykinin receptors, and the suppression of bradykinin activity in prion infected neurons is due to $\mathrm{PrP}^{\mathrm{C}}$-loss-of-function deserves further investigation (Figure 5).

$\mathrm{PrP}^{\mathrm{C}}$ also interacts with ionic channels activated by conformational modification promoted by either voltage and/ or binding to a specific ligand. Once activated, these proteins

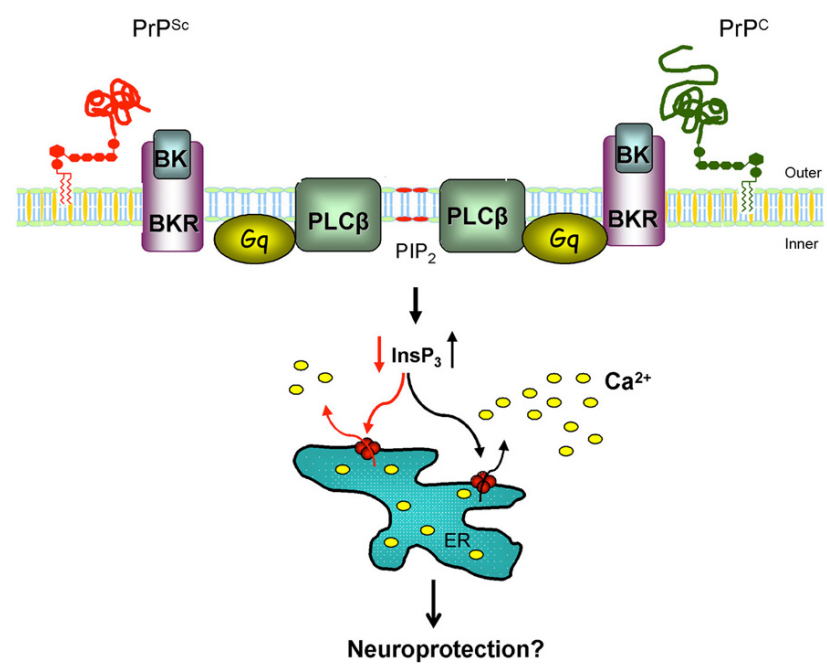

Figure 5. Prion infection impairs mobilization of intracellular $\mathrm{Ca}^{2+}$ by bradykinin. The bradykinin receptor (BKR) is a cell membrane protein coupled to calcium stimulatory $G$ protein $(\mathrm{Gq})$ and to Phospholypase C $\beta$ (PLC $\beta)$. When bradykinin (BK) binds to its receptor, it promotes the PLC $\beta$-catalysed cleavage of phosphatidylinositolbisphosphate (PIP2) into Inositol-3-Phosphate (InsP3). InsP3 promotes calcium release from endoplasmic reticulum (ER), which has been attributed a role against ischemia. In cells infected with $\mathrm{PrP}^{\mathrm{Sc}}$, there is an increase in BKR expression. Paradoxically, there is a reduction of $90 \%$ in InsP3 production, resulting in a decrease of $\mathrm{Ca}^{2+}$ mobilization from the endoplasmic reticulum (red arrows). These effects are attributed to both reduced affinity of $\mathrm{BK}$ for its receptor in this condition, and to a modification of lipid composition in the plasma membrane, with diminished availability of PIP2.

promote changes in the concentrations of $\mathrm{Na}^{+}, \mathrm{K}^{+}, \mathrm{Ca}^{2+}$ or $\mathrm{Cl}^{-}$, thus modulating a variety of electrophysiologicallydependent cellular responses. An interaction between $\mathrm{PrP}^{\mathrm{C}}$ and a two-pore potassium channel protein, TREK (TWIK1-related $\mathrm{K}^{+}$channel), has been demonstrated using a bacterial two-hybrid approach (Azzalin et al., 2006). TREK-1 (Fink et al., 1996) is a protein that forms a mechanicallygated channel activated by temperature, membrane stretch and internal acidosis, and involved in neuroprotection via activation of PKA (Patel and Honore, 2001; Franks and Honore, 2004). Immunoprecipitation assays confirmed the association between both proteins, and that the binding site for TREK localizes at the carboxy-terminal of PrPC (aas 128-230). Confocal analysis demonstrated that fluorescent transfected $\mathrm{PrPC}^{\mathrm{C}}$ and TREK co-localized and, more importantly, that endogenous proteins exhibited colocalization in cerebellar Purkinje cells (Azzalin et al., 2006) (Figure 6A).

The involvement of $\mathrm{PrPC}$ with L-type voltage-gated calcium channels (VGCC) has been first claimed some years ago (Whatley et al., 1995). Reduction of calcium influx, through VGCC, was observed in both cerebellar granule cells and hippocampal neurons slices of $\mathrm{PrP}^{\mathrm{C}}$-null 


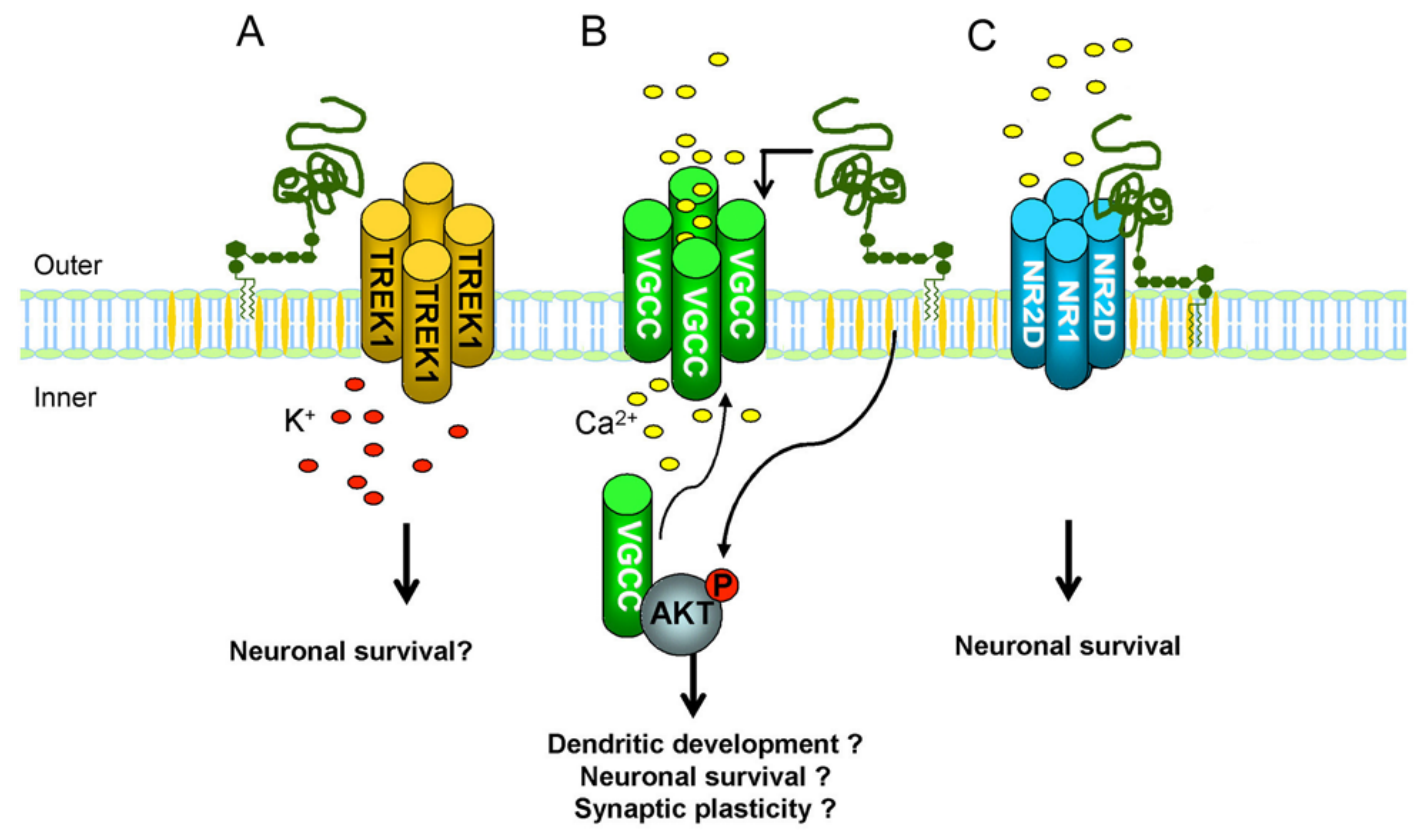

Figure 6. PrPC interacts with or modulates the activity of ionic channels.

A) $\mathrm{PrP}^{\mathrm{C}}$ interacts with a two-pore potassium channel protein (TREK-1), which forms a mechanically-gated $\mathrm{K}^{+}$channel, and reportedly promotes neuroprotection via PKA. B) Voltage gated calcium channels (VGCCs) promote an increase in a cytoplasmic calcium. Cells from $\mathrm{PrP}^{\mathrm{C}}$-null mice present a reduction in calcium influx by VGCCs, probably caused by the impairment in AKT activity and phosphorylation of the VGCC subunits which is an essential step for their insertion in the membrane. C) PrPC interacts with the NR2D subunit of NMDA (N-methyl-D-aspartic acid) receptors, which are ionotropic glutamate receptors permeable to $\mathrm{Ca}^{2+}$. When $\mathrm{PrP}^{\mathrm{C}}$ is absent, the NMDA channel is more sensitive to NMDA, which promotes an increase of calcium influx leding to neuronal cell death.

mice when compared to wild-type neurons (Herms et al., 2000; Fuhrmann et al., 2006). In fact, it is known that VGCC are modulated by PI3K/AKT (Viard et al., 2004), whose activation is fundamental to increase VGCC insertion or prolong their expression at the plasma membrane. There is no evidence of a direct interaction of $\mathrm{PrPC}^{\mathrm{C}}$ with VGCC. However, it is known that activity of PI3K/AKT is diminished $\mathrm{PrP}^{\mathrm{C}}$-null mice (Weise et al., 2006), which may contribute either to a lower insertion or to abbreviate the surface expression of these receptors. One of the most relevant roles of VGCCs is to regulate mechanisms of calcium ions delivery into specific intracellular compartments for a variety of calcium-dependent processes; including dendritic development, neuronal survival, and synaptic plasticity (reviewed by (Moreno, 1999). $\mathrm{PrP}^{\mathrm{C}}$ could then modulate neurotrophic functions indirectly through its positive effect on the activation on VGCC (Figure 6B).

Several studies demonstrated that hippocampal neurons from $\mathrm{PrP}^{\mathrm{C}}$-null mice presented increased excitability when compared to wild-type animals (Collinge et al., 1994; Colling et al., 1996; Mallucci et al., 2002). In vivo studies also showed that, when compared to wild-type mice, $\mathrm{PrPC}_{\text {- }}$ null animals show a lower seizure threshold and higher mortality after treatment with convulsant drugs such as the ionotropic glutamate analog, kainic acid (Walz et al., 1999). Interestingly, $\mathrm{PrP}^{\mathrm{C}}$-null mice presented an elevated susceptibility to neuronal damage induced by kainic acid which is inhibited by the N-methyl-D-aspartate (NMDA) receptor blocker MK-801 (Rangel et al., 2007). NMDA receptors are formed by a tetrameric channel (two NR1 and two NR2 subunits), which are activated by glutamate and are permeable to both sodium and calcium ions (Meldrum, 2000). The expression of NMDA subtypes can be regulated by $\operatorname{PrP}^{\mathrm{C}}$ (Maglio et al., 2004). Remarkably, PrPC associates with NMDA receptors containing NR2D and downregulates their function, preventing depolarization and calcium influx, thus playing a neuroprotective role (Khosravani et al., 2008) (Figure 6C).

\section{$\operatorname{PrP}^{\mathrm{C}}$ shedding and secretion: $\mathrm{PrP}^{\mathrm{C}}$ as a neurotrophic factor}

Despite the preferential $\operatorname{PrP}^{\mathrm{C}}$ localization at the cell surface, as a glycosylphosphatidylinositol (GPI)-anchored protein, this molecule presents alternative topologies that may have inherent physiological functions. Soluble forms of $\mathrm{PrPC}^{\mathrm{C}}$ have been identified not only in the medium of cultured cells (Borchelt et al., 1993; Harris et al., 1993; Parizek et al., 2001; Mattei et al., 2009) but also in human cerebrospinal fluid (Tagliavini et al., 1992), human and murine serum (Parizek et al., 2001; Mattei et al., 2009), and released by human platelets (Perini et al., 1996). At least four mechanisms have been associated to "soluble" forms of PrPC: 1) release to the extracellular space after removal of its GPI-anchor by post-translational modifications possibly caused by escape of glycolipidation (Borchelt et al., 1993; Harris et al., 1993) (Figure 7A); 2) shedding from the cell surface via phospholipase C cleavage of the GPI anchor (Parkin et al., 2004) (Figure 7A); 3) secretion by exosomes (Fevrier et al., 2004) (Figure 7B) and 4) endoproteolytic cleavage by ADAMs (A Disintegrin And Metalloproteases) (Vincent et al., 2001; Cisse et al., 2005) (Figure 7C). 


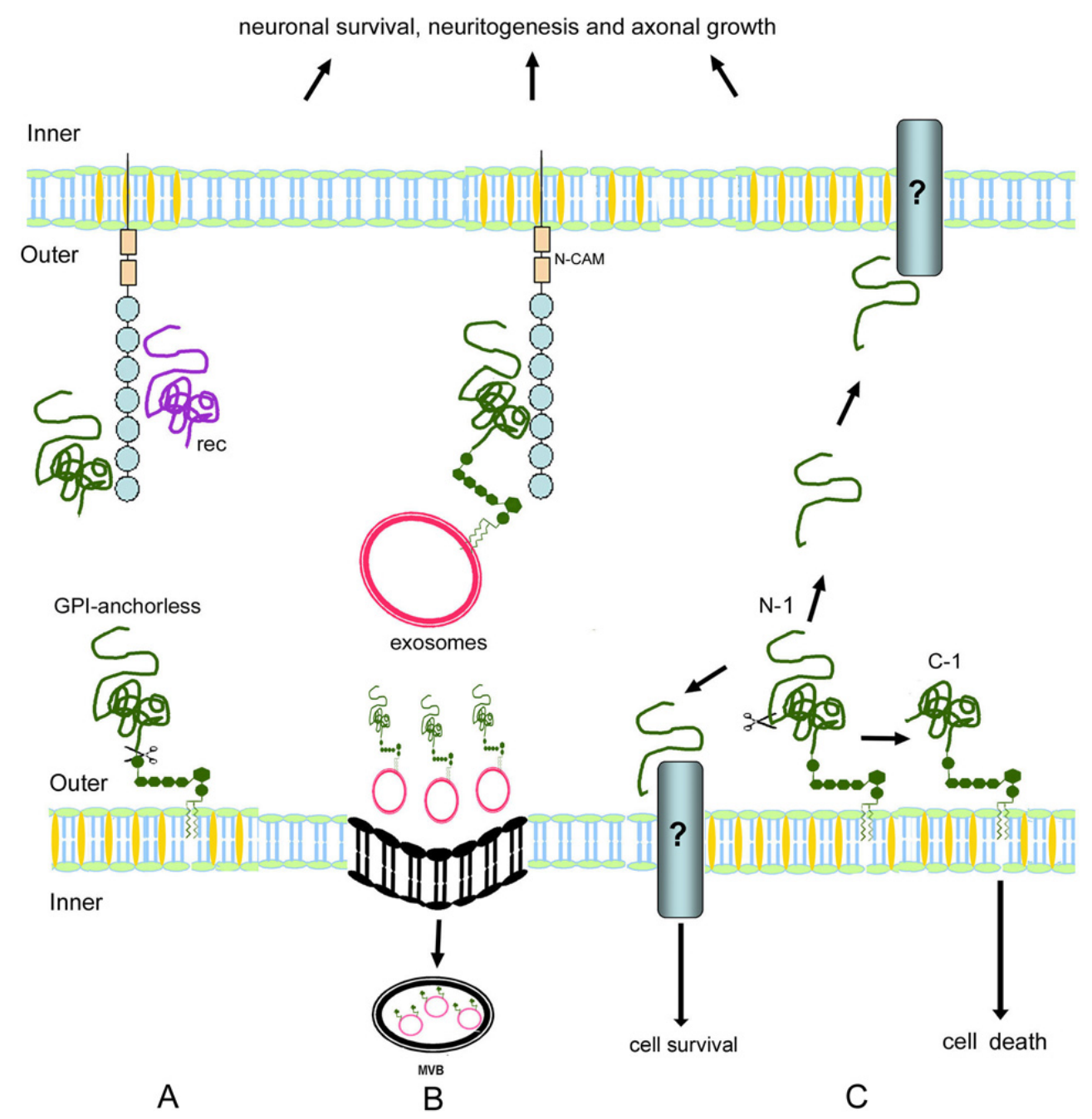

Figure 7. $\mathrm{PrP}^{\mathrm{C}}$ can reach the extracellular space either in exosomes or in soluble forms, and mediate neurotrophic activities. $\mathrm{PrP}^{\mathrm{C}}$ can be released from cells through distinct mechanisms. A) The $\mathrm{PrP}^{\mathrm{C}} \mathrm{GPI}$-anchor can be removed by posttranslational modification or cleaved by phospholipase $\mathrm{C}$. The anchorless $\mathrm{PrP}^{\mathrm{C}}$ found in the extracellular space, as well as exogenous recombinant $\mathrm{PrP}^{\mathrm{C}}$, can bind NCAM and modulate neurotrophic functions. B) $\mathrm{PrP}^{\mathrm{C}}$ is associated with exosomes, which are released by cells upon fusion of multivesicular bodies (MVB) with the plasma membrane. PrPC in exosomos can interact with transmembrane proteins, i.e. NCAM, to transduce neuroprotective effects. C) Metaloproteases cleave PrPC at residues $110 / 111$ generating a soluble $\mathrm{N}$-terminal fragment $(\mathrm{N}-1)$ and a $\mathrm{C}$-terminal fragment $(\mathrm{C}-1)$ tethered to the plasma membrane. The soluble $\mathrm{N}-1$ fragment induces neuronal survival probably by interacting in either cis or trans with an unidentified cell surface receptor. The C-1 fragment tethered to the plasma membrane has pronounced pro-apoptotic activity.

Soluble $\mathrm{PrP}^{\mathrm{C}}$ can act as a ligand triggering neurotrophic functions, and these functions were mimicked in cell cultures by recombinant protein. When mouse primary cerebellar granule neurons were grown in the presence of recombinant $\mathrm{PrPC}^{\mathrm{C}}$, signal transduction components such as PKA, Srcrelated tyrosin kinases, phosphatidylinositol3-kinaseAkt, and MAPK/Erk kinases were activated, promoting neurite outgrowth and neural survival (Chen et al., 2003). In addition, in vitro experiments demonstrated that recombinant $\mathrm{PrPC}$ induces both neuronal survival in mouse cortical neurons (Lima et al., 2007), and rapid neuronal polarization and development of synapses in embryonic rat hippocampal neurons (Kanaani et al., 2005).

Although secreted forms of $\mathrm{PrPC}^{\mathrm{C}}$ were identified in exosomes and microvesicles from neuronal cells, (Fevrier et al., 2004; Mattei et al., 2009), platelets (Robertson et al., 2006) and ovine cerebral spinal fluid (Vella et al., 2008) their biological functions are unknown. Remarkably, PrPC secreted from astrocytes has been associated with neuronal survival (Lima et al., 2007), and vesicular structures containing $\mathrm{PrP}^{\mathrm{C}}$ were identified by biochemical methods and ultrastructural criteria following immunohistochemistry of astrocyte conditioned media (C. Arantes, G. Hajj, M. H. Lopes, I. Porto-Carreiro, R. Linden and V.R. Martins, unpublished observations) (Figure 7B).

$\mathrm{GPI}$-anchored $\mathrm{PrP}^{\mathrm{C}}$ is not a partner for soluble $\mathrm{PrP}^{\mathrm{C}}$, since similar effects were observed when the latter was used to treat either wild-type or $\mathrm{PrP}^{\mathrm{C}}$-null neurons (Chen et al., 2003; Kanaani et al., 2005; Santuccione et al., 2005; Lima et al., 2007). Conversely, NCAM-null neurons 
were unable to respond to soluble $\operatorname{PrP}^{\mathrm{C}}$ (Santuccione et al., 2005), thus indicating that NCAM is required for the neurotrophic functions mediated by physiologically secreted $\mathrm{PrP}^{\mathrm{C}}$ molecules or recombinant $\mathrm{PrP}^{\mathrm{C}}$ (Figures $7 \mathrm{~A}$ and $\mathrm{B}$ ).

$\mathrm{PrP}^{\mathrm{C}}$ is endo-proteolytically cleaved at the N-terminal side, at the $110 / 111$ residues, thus producing a $17-\mathrm{kDa}$ $\mathrm{C}$-terminal fragment $\mathrm{C} 1$ tethered to the plasma membrane (Harris et al., 1993; Chen et al., 1995; Laffont-Proust et al., 2005). The 9-kDa soluble $\mathrm{N}$-terminal counterpart referred as $\mathrm{N}-1$ is constitutively released in the extracellular medium depending on protein kinase C (Vincent et al., 2000). Three disintegrins contribute to this processing, either directly such as ADAM-10 and -17 (Vincent et al., 2001) or indirectly such as ADAM-9 (Cisse et al., 2005). The activation of muscarinic receptor increases the physiological processing of $\mathrm{PrPC}$ through upregulation of the phosphorylation and activity of ADAM-17 (Alfa et al., 2007).

The C-terminal fragment that remains attached to the cell membrane (C-1) displays pro-apoptotic functions and regulates p53 mRNA transcription and activity (Sunyach et al., 2007) (Figure 7C). Conversely, a recombinant N-1 fragment protected cells from staurosporine-induced apoptosis, by reducing caspase- 3 activity, p53 promoter trans-activation and activity as well as p53 mRNA levels (Sunyach in preparation, cited in (Vincent et al., 2008) (Figure 7C). These data indicate that opposite effects of $\mathrm{C}-1$ and $\mathrm{N}-1$ domains may maintain an appropriate balance between cell survival and death.

The mechanisms associated to the pro- and antiapoptotic effects of the $\mathrm{C}-1$ and $\mathrm{N}-1 \mathrm{PrP}^{\mathrm{C}}$ fragments remain unknown, and deserve further investigation. These effects may be due to the inability of the membrane-bound C-1 to bind and/or to modulate certain $\operatorname{PrP}^{\mathrm{C}}$ partners such as GAG, vitronectin, ligands involved in the neurotrophic role of $\mathrm{PrP}^{\mathrm{C}}$, or LRP1, which binds $\mathrm{PrP}^{\mathrm{C}}$ between amino acids 23-107 and is involved with internalization of $\operatorname{PrP}^{C}$ (Parkyn et al., 2008). However, the anti-apoptotic role of $\mathrm{PrP}^{\mathrm{C}}$ has been ascribed to the cAMP/PKA pathway (Lopes et al., 2005), and neither the activation of this pathway nor its survival-promoting role appear to be dependent on endocytosis (Caetano et al., 2008). On the other hand, the protective effects of $\mathrm{N}-1$ fragment can occur after its interaction in either cis or trans with unidentified cell surface proteins (Figure 7C).

Therefore, both $\mathrm{GPI}$-anchored and soluble $\mathrm{PrP}^{\mathrm{C}}$, present overlapping neurotrophic properties. This is consistent with the hypothesis that $\operatorname{PrPC}^{C}$ functions as a cell surface scaffolding protein, since the relative preservation of the structure of $\mathrm{PrP}^{\mathrm{C}}$ irrespective of its anchoring into the plasma membrane would allow similar molecular interactions of either the membrane-bound or the released forms (Linden et al., 2008). Nonetheless, small structural changes of PrPC upon interaction with lipids (Morillas et al., 1999; Eberl et al., 2004; Hicks et al., 2006) may affect interaction of PrPC with its ligands. It is possible that neurotrophic effects of the GPI-anchored PrPC may be complemented by specific regulation of $\mathrm{PrP}^{\mathrm{C}}$ secretion, shedding and cleavage.

\section{$\mathrm{PrP}^{\mathrm{C}}$ localization in specific membrane microdomains and $\mathrm{PrP}^{\mathrm{C}}$ cellular traffic modulate neurotrophic functions}

Lipid rafts form an ordered phase in membranes rich in cholesterol and sphingolipids and are likely to be the sites where GPI-anchored proteins are preferentially partitioned.
It has long been recognized that $\mathrm{PrP}^{\mathrm{C}}$, as other GPIanchored proteins (Fivaz et al., 2002), is present in lipid rafts (Naslavsky et al., 1997). Early work indicated that $\mathrm{PrPSc}^{\mathrm{Sc}}$ was present in caveole-like domains in brain tissue (Vey et al., 1996), however pioneer studies using chicken $\mathrm{PrPC}^{\mathrm{C}}$ showed that the protein is sequestered from the cell surface in clathrin-coated pits (Shyng et al., 1994). This work received some initial criticism, due to the perceived default pathway of internalization of GPI-anchored proteins by caveolae and other non-clathrin mediated pathways (Vey et al., 1996). However, recent work has shown that $\mathrm{PrPC}^{\mathrm{C}}$ in neurons and neuronal cells is indeed predominantly sequestered by a clathrin-mediated pathway (Sunyach et al., 2003). Both dynamin K44A, a dominant-negative inhibitor of dynamin activity (Magalhaes et al., 2002), and AP-180C, the C-terminal fragment of the endocytic protein AP180, when overexpressed in cells block the internalization of $\mathrm{PrP}^{\mathrm{C}}$ (Taylor and Hooper, 2007). Both these treatments have been suggested to block selectively clathrin-mediated endocytosis, albeit dynamin K44A also appears to interfere with caveolae-dependent endocytosis (Prado et al., 2004). Co-localization experiments in neurons shows that mammalian $\mathrm{PrPC}^{\mathrm{C}}$ is found in clathrin-coated vesicles that also internalize transferrin (Sunyach et al., 2003). In addition, a motif in the N-terminus of cellular prion $\left({ }^{23} \mathrm{KKRPKP}^{28}\right)$ appears to be critical for clathrin-mediated endocytosis (Sunyach et al., 2003). These results agree with earlier assessment that found GFP-PrPC in Rab5positive endocytic vesicles (Magalhaes et al., 2002).

These observations raise the possibility that $\operatorname{PrPC}^{C}$ uses alternative mechanisms other than its GPI-anchor for internalization. A minimum GPI-anchored protein GFP-GPI, utilizes non-clathrin mediated endocytosis as a pathway for internalization (Nichols et al., 2001). Hence, it appears that the GPI-anchor of $\mathrm{PrP}^{\mathrm{C}}$ does not contribute majorly for its sequestration from the cell surface. Alternative mechanisms of internalization for GPI-anchored proteins have been suggested. For example, the urokinase plasminogen activator receptor (UPAR, a GPI-anchored protein) piggybacks onto the low-density lipoprotein receptor-related protein (LRP1, a transmembrane scavenger protein that can interact with intracellular adaptor proteins) to be internalized (Nykjaer et al., 1992; Conese et al., 1995; Czekay et al., 2001). Manipulations that alter LRP1 expression or its interaction with ligands (using the chaperone RAP for example) decrease the internalization of $\mathrm{PrP}^{\mathrm{C}}$, suggesting that $\mathrm{PrP}^{\mathrm{C}}$ may follow a similar internalization pathway by piggybacking with LRP1 (Taylor et al., 2007; Parkyn et al., 2008). Since $\mathrm{PrPC}^{\mathrm{C}}$ is found in clathrin-coated vesicles (Sunyach et al., 2003) it might be possible that this is the patway used to internalize PrPC-LRP1 (Figure 8A). Moreover, LRP1 appears to have additional roles in $\mathrm{PrPC}$ trafficking, as this scavenger receptor appears to interact with $\mathrm{PrPC}^{\mathrm{C}}$ during its biosynthesis, perhaps acting like a chaperone for PrPC (Parkyn et al., 2008).

The 37LRP/67LR also promotes $\mathrm{PrPC}^{\mathrm{C}}$ internalization, even though this has been observed only for the recombinant protein and no internalization pathway has been described (Gauczynski et al., 2001) (Figure 8B).

Recent work from our laboratories suggested that at least for one $\mathrm{PrP}^{\mathrm{C}}$ ligand, STI1, their binding triggers endocytosis of the prion protein (Caetano et al., 2008). Copper has been previously shown to interact with $\mathrm{PrP}^{\mathrm{C}}$ and to trigger 
A B $\quad$ C

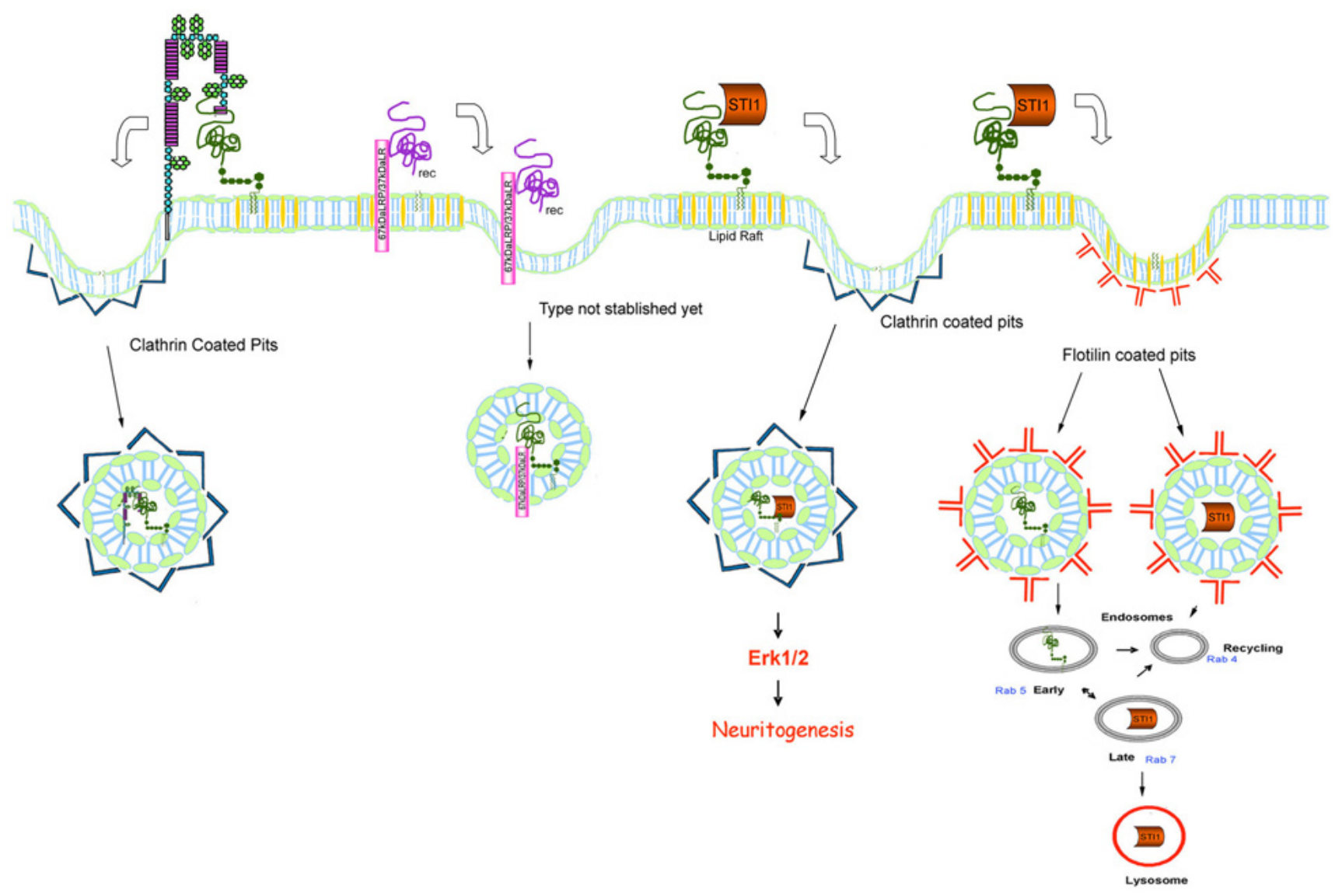

Figure 8. Distribution of $\mathrm{PrPC}$ in specific membrane microdomains and endocytic vesicles mediates neurotrophic functions. A) LRP interacts with $\mathrm{PrP}^{\mathrm{C}}$ located in lipid rafts and triggers the latter's internalization. B) 37LRP/67LR promotes the internalization of recombinant $\mathrm{PrPC}$ through an unknown mechanism. C) STI1 induces PrPC internalization by clathrin coated pits. ERK1/2 activation depends of $\mathrm{PrP}^{\mathrm{C}}$ internalization. D) $\mathrm{PrP}^{\mathrm{C}}$ and $\mathrm{STI} 1$ were also found in flotillin/reggie1 vesicles, recycling vesicles and lysosomes.

its endocytosis (Pauly and Harris, 1998; Lee et al., 2001; Perera and Hooper, 2001). Hemin (iron protoporphyrin IX) added to culture media can also evoke $\mathrm{PrPC}^{\mathrm{C}}$ internalization and recycling (Lee et al., 2007b). However, to the best of our knowledge, STI1 is the first ligand, which triggers cellular signaling by interacting with $\operatorname{PrP}^{\mathrm{C}}$ that can also evoke sequestration of this protein. Internalization of cell surface receptors is usually considered a mechanism for modulation of cellular responses (Ferguson, 2001), suggesting the possibility that endocytosis of $\mathrm{PrP}^{\mathrm{C}}$ triggered by STI1 may be involved in cellular signaling.

This possibility received initial support when it was found that treatments known to decrease endocytic activity in cells diminished STI1 mediated signaling (Americo et al., 2007). Recent work showed that a PrPC mutant $\left({ }^{23} \mathrm{KKRPKP}{ }^{28}\right.$ to ${ }^{23} \mathrm{KQHPSP}^{28}$ ), that fails to undergo clathrin-mediated endocytosis (Sunyach et al., 2003), can reconstitute $\mathrm{PrP}^{\mathrm{C}}$ mediated activation of PKA in response to STI1, but not activation of ERK1/2 activation in the same condition (Caetano et al., 2008). The most parsimonious explanation for these results is that activation of ERK1/2, but not PKA triggerd by STI1-PrPC interaction depends on the internalization of $\mathrm{PrP}^{\mathrm{C}}$ into clathrin-coated vesicles (Figure $8 C)$.

Interestingly, the activation of ERK1/2 induced by STI1 is fast and transient, lasting no more than a few minutes (Lopes et al., 2005; Caetano et al., 2008). This observation has led us to investigate if STI1 trafficking in cells could explain the short activation time of ERK1/2. Indeed, STI1 is also internalized by cells in a $\mathrm{PrP}^{\mathrm{C}}$ independent-way. A fraction of STI1 appears to be internalized with $\mathrm{PrPC}^{\mathrm{C}}$ and, in the initial moments of internalization part of STI1 is found in clathrin-coated vesicles. However, shortly after internalization STI1 and PrPC appear to be sorted to distinct intracellular paths, and upon prolonged chase they distribute to distinct intracellular compartments (Caetano et al., 2008). Remarkably, most internalized STI1 is eventually found in flotillin/reggie-positive vesicles (Figure 8C). We have speculated that the divergence in intracellular roads taken by the two proteins may function to attenuate ERK $1 / 2$ signalling (Caetano et al., 2008).

$\mathrm{PrP}^{\mathrm{C}}$ was also found in flotillin/reggie-1 lipid rafts in non-neuronal cells, suggesting that, at least in certain circumstances $\mathrm{PrPC}^{\mathrm{C}}$ and STI1 could share the same 
internalization pathway. $\mathrm{PrPC}^{\mathrm{C}}$ was targeted to these domains through antibody cross-linking, leading to actin polymerization, ERK1/2 phosphorylation and a distinct brief $\mathrm{Ca}^{2+}$ signal (Stuermer et al., 2004). These results also imply that $\mathrm{PrP}^{\mathrm{C}}$ sequestration and activity are coupled events. Reggie/flotilins are cytoplasmic proteins involved in the capping of raft derived vesicles, and can also be found in the nervous system. Their ablation induces morphological defects in the nervous system during embryogenesis (Stuermer and Plattner, 2005), and they are involved in the secretion of morphogens such as Hedgehog and Wnt in Drosophila (Katanaev et al., 2008). Since both PrPC and STI1 can be secreted, the interaction of these proteins with reggie/flotillin-positive organelles may have important implications for the availability of secreted $\mathrm{PrPC}^{\mathrm{C}}$ or STI1 (Figure 8D).

The possibility that $\mathrm{PrP}^{\mathrm{C}}$ endocytosis is a triggered event related to cellular signaling merits further investigation. For example, as demonstrated in Figure $6 \mathrm{C}, \mathrm{PrP}^{\mathrm{C}}$ at the cell surface has been shown recently to constitutive silence the NR2D receptor subunit in hippocampal neurons (Khosravani et al., 2008). This subunit, when incorporated to functional NMDA receptors generates currents with long decay kinetics, which may be responsible for increased sensitivity to excitotoxicity in $\mathrm{PrP}^{\mathrm{C}}$-null neurons (Khosravani et al., 2008). It could be envisioned that sequestration of cell surface $\mathrm{PrP}^{\mathrm{C}}$ may be a mechanism to transiently increase NMDA currents in hippocampal neurons. Another potential site for regulation is the $\beta$-secretase pathway involved in APP processing that has been recently shown to be regulated by the presence of $\mathrm{PrP}^{\mathrm{C}}$ in lipid rafts (Parkin et al., 2007). Future experiments aimed at dissecting signaling complexes involved in $\mathrm{PrP}^{\mathrm{C}}$ function, should also target the mechanisms through which these complexes regulate and are regulated by cellular prion trafficking.

\section{$\operatorname{PrP}^{\mathrm{C}}$ in astrocytes promoting neuronal survival and differentiation}

Astrocytes and neurons interact in various neurophysiological events and represent an integral unit in brain function. Astrocytes are key elements in both the production of neurotrophic molecules and controlling the levels of neurotoxic substances. They can also modulate the production of extracellular matrix that supports neuronal development and differentiation (Theodosis et al., 2008).

The functions of $\mathrm{PrPC}^{\mathrm{C}}$ in astrocytes are largely unknown. It was shown that $\mathrm{PrP}^{\mathrm{C}}$ associates with both the GluR2 subunit of AMPA receptors and $2 \alpha / \beta 2 \mathrm{Na}^{+} / \mathrm{K}^{+} \mathrm{ATPase}$. The latter binds to basigin, a cell adhesion molecule (Kleene et al., 2007), which is tightly associated with the lactate monocarboxylate transporter 1 (MCT1). In the absence of glutamate, the $2 \alpha / \beta 2 \mathrm{Na}^{+} / \mathrm{K}^{+}$ATPase is less active, and MCT1 does not transport lactate. Conversely, when glutamate is present, MCT1 is active, leading to either increased release or uptake of lactate, depending on the concentration of the latter inside and outside of the astrocyte. Intense synaptic activity implies an increased energy demand, and lactate provided by astrocytes may be a necessary alternative substrate for balancing the energetics of neuronal activity. Deletion of $\mathrm{PrP}^{\mathrm{C}}$ is followed by inactivation of $2 \alpha / \beta 2 \mathrm{Na}^{+} / \mathrm{K}$ ${ }^{+}$ATPase, and an interruption on the control of MCT1, which becomes permanently active even in the absence of glutamate. It was suggested that the deletion of $\operatorname{PrP}^{\mathrm{C}}$ may result in increased levels of extracellular lactate, and lactateinduced acidosis leading to neuronal damage (Kleene et al., 2007). The $\mathrm{PrP}^{\mathrm{C}}$-dependent protein complex involved in lactate transport may therefore play an important role upon synaptic function (Figure 9A).

The role of $\mathrm{PrP}^{\mathrm{C}}$ in neurotrophic interactions between astrocytes and neurons has also been addressed (Lima et al., 2007). Prominent neurite outgrowth was observed when wild-type neurons were co-cultured with wild-type astrocytes, while poor differentiation was present when both cells were derived from $\mathrm{PrP}^{\mathrm{C}}$-null mice. It is possible that $\mathrm{PrP}^{\mathrm{C}}$ in astrocytes contributes to neurite outgrowth by transactivating a ligand such as NCAM in neurons (Figure 9B). In addition, astrocytes produce and secrete laminin, among other ECM proteins. Laminin secreted and deposited at the ECM by wild-type astrocytes showed a fibrilar organization (Figure 9B), while that secreted from $\mathrm{PrP}^{\mathrm{C}}$-null astrocytes has a punctate pattern (Figure $9 \mathrm{C}$ ). The pattern of laminin matrix has been shown to influence neurite outgrowth (Freire et al., 2002), either through modulation of its binding to PrPC (Graner et al., 2000a) or to other cell surface receptors (Denda and Reichardt, 2007; Nelson et al., 2008).

Astrocytes also release soluble neurotrophic factors and proteins such as STI1 and PrPC (Lima et al., 2007) and these proteins can bind to neuronal $\mathrm{PrP}^{\mathrm{C}}$ and NCAM respectively, mediating neuronal survival and differentiation (Lima et al., 2007). Neuronal survival was higher when cells where treated with conditioned medium from wild-type astrocytes, as compared with medium from $\mathrm{PrP}^{\mathrm{C}}$-null astrocytes. These data clearly show that $\mathrm{PrP}^{\mathrm{C}}$ in astrocytes is critical to sustain cell-cell interaction, organization of extracellular matrix and secretion of soluble factors, thus helping to maintain a healthy environment for neuronal survival and differentiation (Figures 9B and $\mathrm{C}$ ).

Therefore, $\mathrm{PrP}^{\mathrm{C}}$ not only works as a neurotrophic factor for neuronal cells, but also modulates astrocyte performance on neuronal survival and differentiation.

\section{$\mathrm{PrP}^{\mathrm{C}}$ as a therapeutic target for degenerative illnesses}

Given that $\mathrm{PrP}^{\mathrm{C}}$ interacts with several classes of molecules triggering neurotrophic functions, and the high expression of $\mathrm{PrPC}^{\mathrm{C}}$ in the nervous system, it is conceivable that the modulation of $\mathrm{PrP}^{\mathrm{C}}$ activity and its interaction with specific ligands may constitute therapeutic targets not only for prion diseases, but also for other chronic degenerative diseases.

The pathogenesis of prion diseases can be explained, at least in part, by "loss-of-function" mechanism, which consists in the depletion of the neuroprotective function of $\mathrm{PrP}^{\mathrm{C}}$, when converted to PrPSc. However, this mecanism is still debatable, due to some noteworthy results. For example, the deletion of neuronal $\mathrm{PrP}^{\mathrm{C}}$ in adult mice causes changes in some hippocampal properties, but no neurodegeneration (Mallucci et al., 2002). Spongiosis, neuron loss, cognitive and behavioral deficits, as well as impaired neurophysiological function, were reverted upon deletion of $\mathrm{PrPC}^{\mathrm{C}}$ in early stages of the disease in mice (Mallucci et al., 2003; Mallucci et al., 2007). Remarkably, these results were reproduced when the expression of $\mathrm{PrP}^{\mathrm{C}}$ was inhibited by a lentiviral vector containing an anti$\mathrm{PrP}^{\mathrm{C}}$ shRNA in prion infected mice (White et al., 2008). This treatment also significantly prolonged the survival of those animals (White et al., 2008). Thus, despite limitations such as treatment in early stages of prion disease, the need 

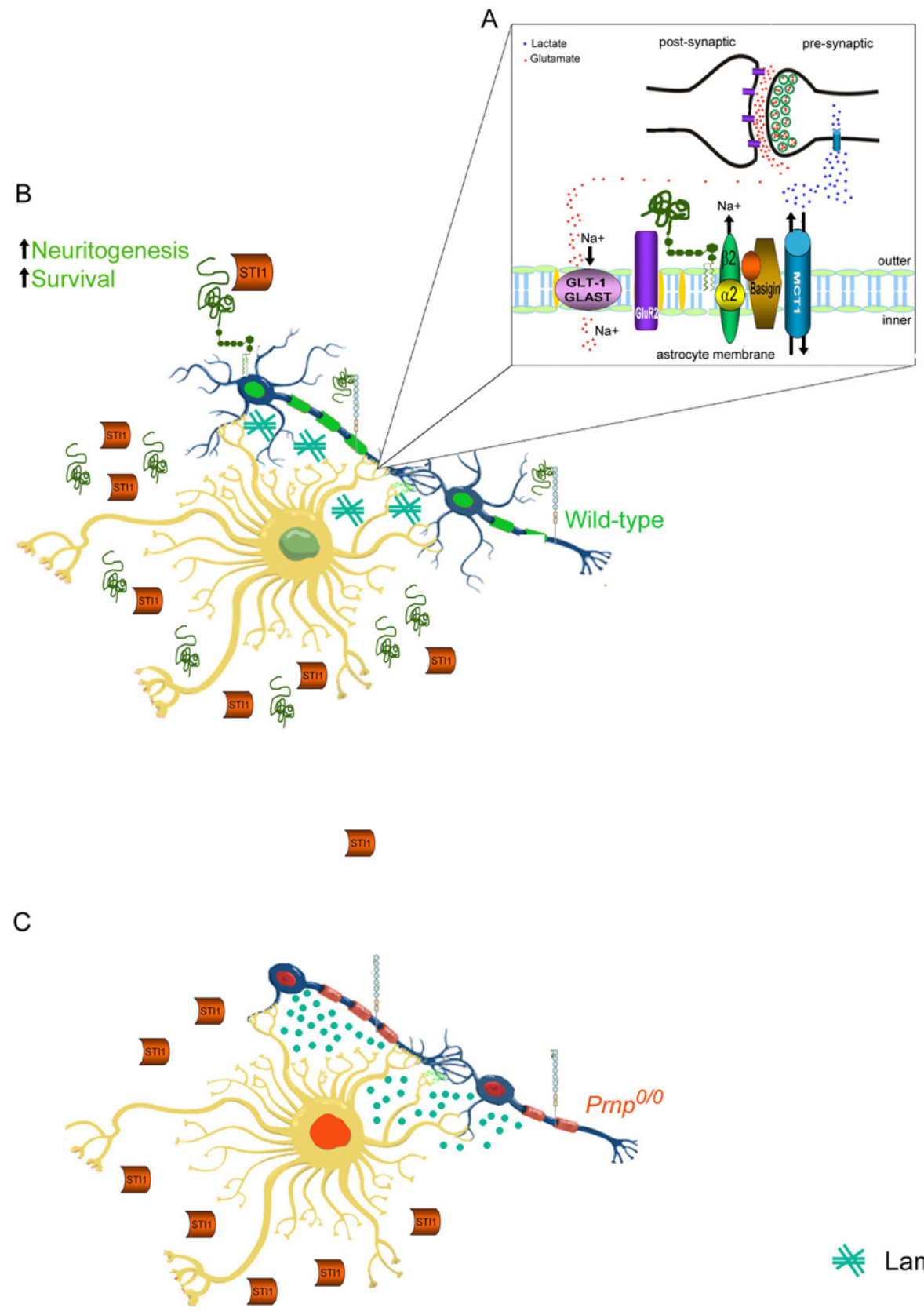

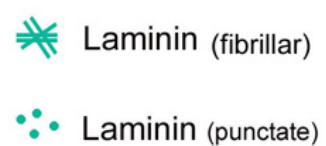

NCAM

Figure 9. $\mathrm{PrP}^{\mathrm{C}}$ modulates neurotrophic properties in astrocytes. A) Glutamate released in synapses is taken up by astrocytes via glial glutamate transporters (GLAST/GLT-1). $\mathrm{Na}^{+}$dependent transport of glutamate causes a massive $\mathrm{Na}^{+}$influx into the cell, leading to the activation of the $\mathrm{Na}^{+} / \mathrm{K}^{+}$ATPase. In order to maintain a high glycolitic flux, lactate is released from astrocytes into the extracellular space via the monocarboxylate trasporter (MCT-1). Lactate is taken up by neurons. PrPC associates with a protein-complex involved in lactate transport in the astrocytic membrane. PrPC can directly interact with both, the GluR2 subunit of AMPA receptors and $2 \alpha / \beta 2 \mathrm{Na}^{+} / \mathrm{K}^{+}$ATPase. The latter binds a cell adhesion molecule, basigin, required as an auxiliary protein to maintain the catalytic activity of the lactate receptors. The lack of $P r P^{C}$ reduces the $2 \alpha / \beta 2$ $\mathrm{Na}^{+} / \mathrm{K}^{+}$ATPase pump activity and activates basigin/MCT1 associate lactate transport. B and C) PrPC and STI1 as neurotrophic factors in neuron-glia interaction. A prominent neuritogenesis is observed when wild-type neurons are co-cultured with wildtype astrocytes $(B)$ neurite outgrowth is impaired when both cell types are derived from $\mathrm{PrP}^{\mathrm{C}}$-null mice $(\mathrm{C})$. Laminin secreted and deposited at the ECM by wild-type astrocytes has a fibrillar organization and promotes more intense neurite outgrowth than the puctated laminin secreted from $\mathrm{PrP}^{\mathrm{C}}$-null astrocytes. Astrocytes also release $\mathrm{STI} 1$ and $\mathrm{PrPC}$, which induce neuronal survival and differentiation. 
for transport across the blood-brain barrier, and off-target effects, anti-PrPC ${ }^{C}$ siRNA seems to be a promising approach to treat prion diseases. Notwithstanding, its effect regarding $\mathrm{PrP}^{\mathrm{C}}$ loss-of-function in humans need to be considered. Still, short lived side effects may be acceptable, due to the devastating characteristics of prion diseases.

The use of anti-PrPC antibodies to block prion infection in vivo has also been addressed, but some of the data are contraditory, particulary regarding the toxicity of the treatment. The expression of a transgenic anti-PrPC $\operatorname{lgMa} \mu$ chain prevented pathogenesis of prions directly inoculated into brain or spleen (Heppner et al., 2001). In addition, peripheral infection was markedly reduced by treatment with anti-PrPC antibodies (White et al., 2003). Extracerebrally infected CD-1 mice also presented effective suppression of $\mathrm{PrP}^{\mathrm{Sc}}$ replication in the lymphoreticular system, lengthening of the incubation period and a significant decrease in CNS pathology after treatment with anti-PrPC antibodies (Sadowski et al., 2009). However, important concerns about intracerebral treatment with antibodies to $\operatorname{PrP}^{\mathrm{C}}$ were raised (Tayebi and Hawke, 2006). The cross-linking of PrPC in vivo with specific monoclonal antibodies triggers rapid and extensive apoptosis in hippocampal and cerebellar neurons (Solforosi et al., 2004). Prolonged treatment with $\mathrm{PrPC}^{\mathrm{C}}$ antibodies also causes extensive neuronal loss, strong astrogliosis and microglial activation, even when IgG Fab fragments were applied (Lefebvre-Roque et al., 2007). In addition, this treatment was not protective against the development of BSE in transgenic mice overexpressing PrPC $^{C}$ (Lefebvre-Roque et al., 2007).

Blockade of $\mathrm{PrP}^{\mathrm{C}}-\mathrm{PrP}^{\mathrm{Sc}}$ conversion without altering $\mathrm{PrP}^{\mathrm{C}}$ function is also an interesting alternative for prion diseases. This has been approached through the targeting of physiological ligands already characterized as inhibitors of $\mathrm{PrP}^{\mathrm{C}}$ conversion into $\mathrm{PrP}^{\mathrm{Sc}}$. A trans-dominant negative 37LRP/67LR mutant reportedly had an inhibitory effect on $\mathrm{PrP}^{\mathrm{C}}$-PrPSc conversion in vitro (Vana and Weiss, 2006). Preclinical studies demonstrated that passive immunotransfer of single chain Fvantibodies directed against the 37LRP/67LR reduced $\mathrm{PrPSc}$ levels in the spleen of prion infected mice (Zuber et al., 2008). Stereotatic intracerebral microinjection of adeno-associated virus (AAV) vectors expressing single chain Fv antibodies against this receptor leads to a reduction of peripheral PrPSc, however without a significant lenghtening of incubation times and survival (Zuber et al., 2008). In this line, other candidate targets may be glycosaminoglycans (GAGs), which have both high affinity for $\mathrm{PrP}^{\mathrm{C}}$ and demonstrated anti-scrapie activities (Caughey et al., 1994; Warner et al., 2002; Schonberger et al., 2003; Kocisko et al., 2006; Caughey et al., 2006; Silva et al., 2008). Further studies are required to test how the modulation of these molecules for the treatment of prion diseases may affect physiological functions of $\mathrm{PrPC}$.

$\mathrm{PrP}^{\mathrm{C}}$ may also be approached as a candidate neuroprotective agent in Alzheimer's disease, due to its effect of downmodulating the activity of $\beta$-secretase, therefore decreasing the production of the toxic amyloid- $\beta$ $(A \beta)$ peptide, the main component of senile plaques (Parkin et al., 2007). On the other hand, $\operatorname{PrP}^{\mathrm{C}}$ was also found to be the major receptor for $A \beta$ oligomers in neurons and their interaction is important for the effects of $A \beta$ on synaptic disfunction (Lauren et al., 2009). The possible use of $\operatorname{PrPC}^{\mathrm{C}}$ as a therapeutic target in Alzheimer diseases has been explored (Parkin et al., 2007; Lauren et al., 2009), and the development of reagents that increase $\beta$-secretase inhibition by $\mathrm{PrP}^{\mathrm{C}}$ and impair $\mathrm{PrP}^{\mathrm{C}}-\mathrm{A} \beta$ oligomers binding would be desirable.

Although exogenous GAGs may constitute lead compounds for the development of therapeutic methods for prion diseases (Schonberger et al., 2003), the same can be detrimental for Alzheimer's disease. Whereas $\mathrm{PrPC}$ interacts with BACE1 therefore inhibiting its $\beta$-secretase activity, the interaction between $\mathrm{PrP}^{\mathrm{C}}$ and BACE1 involves GAGs, and the exogenous GAGs appear to disrupt this interaction, thus restoring the production of $A \beta$ peptides (Parkin et al., 2007). Still, exploring $\mathrm{PrP}^{\mathrm{C}}$-GAGs interactions would potentially generate new and improved therapeutic strategies for both prion and Alzheimer's diseases.

Both the differentiation of dorsal root ganglia (Hajj et al., 2007) as well as motor neuron survival (Barbeito A., Hajj G, Martins VR, Barbeito L unpublished results) can be modulated by $\operatorname{PrP}^{C}$. Although previous results suggested downregulation of $\mathrm{PrPC}^{\mathrm{C}}$ in a transgenic mouse model for amyotrophic lateral sclerosis (ALS) (Dupuis et al., 2002) our data demonstrated that $\mathrm{PrP}^{\mathrm{C}}$ expression in tissues from similar animals are comparable to their normal counterpart (Barbeito A., Hajj G, Martins VR, Barbeito L unpublished results). Therefore, protective effects of $\mathrm{PrPC}^{\mathrm{C}}$ in motor neurons can also become a therapeutic target for ALS, and this hypothesis deserves to be explored.

It has been reported that $\operatorname{PrP}^{\mathrm{C}}$ depletion causes a higher aggregation of huntingtin $(\mathrm{Htt})$, similar to what is observed when cells are treated with a proteasome inhibitor. Conversely, overexpression of $\mathrm{PrPC}^{\mathrm{C}}$ in cells expressing $\mathrm{Htt}$ caused a decrease in both the number of cells with $\mathrm{Htt}$ granules and the number of apoptotic cells, indicating a protective activity of $\mathrm{PrPC}^{\mathrm{C}}$ against pathological protein aggregation (Lee et al., 2007a). Histone deacetylase (HDAC) inhibitors have been proposed as a novel therapeutic approach for the Huntington's disease (Sadri-Vakili and Cha, 2006) and $\mathrm{PrP}^{\mathrm{C}}$ is upregulated by such inhibitors (Cabral et al., 2002). Altogether, these data suggest that $\mathrm{PrPC}^{\mathrm{C}}$ should be considered in attempts to develop new therapeutic approaches for Huntington's disease.

The protective function of $\mathrm{PrP}^{\mathrm{C}}$ extends to other neurological disorders such as epilepsy. Two independent studies demonstrated that $\mathrm{PrP}^{\mathrm{C}}$-null mice are more susceptible to seizures induced by convulsant agents (Walz et al., 1999; Rangel et al., 2007). After injection of kainate or pentylenetetrazol, these animals presented higher grade seizures reaching elevated mortality and increased neuronal death when compared with control mice (Walz et al., 1999; Rangel et al., 2007). Moreover, several brain regions of $\mathrm{PrP}^{\mathrm{C}}$-null mice showed increased neuronal death upon injections of kainate (Rangel et al., 2007). The absence of $\mathrm{PrP}^{\mathrm{C}}$ decreased the activity of GABAergic receptors (Collinge et al., 1994) and increased the expression and activity of NMDA receptors (Maglio et al., 2004; Khosravani et al., 2008). Thus, the neuroprotective function of $\mathrm{PrPC}^{\mathrm{C}}$ against seizures may be a consequence of its ability to balance inhibitory and excitatory synaptic transmission (Khosravani et al., 2008).

The expression of $\mathrm{PrPC}^{\mathrm{C}}$ is also important for the maintenance of the circadian rhythm and sleep homeostasis. Animals that do not express $\mathrm{PrPC}^{\mathrm{C}}$ presented longer period of activity in free-running conditions compared to normal mice 
and this phenotype was rescued with re-expression of $\mathrm{PrPC}$ (Tobler et al., 1996). Moreover, the lack of $\mathrm{PrP}^{\mathrm{C}}$ expression increased the sleep fragmentation indicating that $\operatorname{PrP}^{C}$ is required for sleep continuity (Tobler et al., 1996; Tobler et al., 1997). Consistently, patients with prion diseases also present altered sleep patterns that can extend to the case of patients carrying a mutation Asp178 Asn that leads to fatal familial insomnia (Landolt et al., 2006; Provini et al., 2008). Since sleep is a physiological process tightly controlled by various neurotransmitter systems, these data corroborate the view that $\mathrm{PrP}^{\mathrm{C}}$ can be a target to modulate synaptic transmission and for the treatment of sleep disorders.

Finally, $\operatorname{PrP}^{\mathrm{C}}$ can also be a target for the treatment of acute injuries. The induction of ischemic stroke in the animal model generates complex pathophysiological conditions in the brain that can culminate with cell death. This experimental approach was used by several groups to evaluate the neuroprotective role of $\mathrm{PrP}^{\mathrm{C}}$ in vivo. All findings unanimously demonstrated that ischemic lesions increased the local expression of $\mathrm{PrP}^{\mathrm{C}}$ and that $\mathrm{PrP}^{\mathrm{C}}$-null mice were more vulnerable to the ischemic stroke presenting larger brain injury (McLennan et al., 2004; Weise et al., 2004; Shyu et al., 2005; Weise et al., 2006). The up-regulation of PrPC due to the ischemic stroke was also observed in human post-mortem brain tissue. Pyramidal neurons, inflammatory cells and micro vessels of the peri-infarcted area expressed higher level of $\mathrm{PrP}^{\mathrm{C}}$ compared to contralateral tissues (Mitsios et al., 2007). Moreover, a higher level of PrPC was also present in the plasma (Mitsios et al., 2007). The upregulation of $\mathrm{PrP}^{\mathrm{C}}$ expression in the ischemic tissue may represent a protective mechanism against the injury and might conceivably be explored therapeuticaly.

\section{Conclusion and future directions}

Studies of neurotrophic signal transduction have evolved from the search for simple pathways controlling cell survival to complex, non-linear systems, including interactions of classic neurotrophic factors (Sharma, 2007; Sanford et al., 2008; Hossain et al., 2008), cross-talk and transactivation among differing neuroactive molecules and membrane receptors (Lee et al., 2002; Wiese et al., 2007; Jeanneteau et al., 2008; Iwakura et al., 2008), selective, and even opposite, responses either of individual receptors or to single neurotrophic molecules (Chao et al., 2002; Iwakura et al., 2008), modulation of receptor expression and exposure (Nagappan and Lu, 2005), as well as subcellular trafficdependent signaling (Howe and Mobley, 2005; Ibanez, 2007; Cosker et al., 2008).

Scaffolding proteins provide for both spatial coordination and kinetics of molecular interactions, which are critical for the selective activation of signaling cascades within the intracellular environment (Pawson and Scott, 1997; Bhattacharyya etal., 2006; Murrin and Talbot, 2007; Jarnaess and Tasken, 2007; Bezman and Koretzky, 2007; Dohlman, 2008). A number of intracellular scaffolding proteins are required for signaling downstream of membrane receptors and for interaction of known neurotrophic molecules (Nakaoka et al., 2003; Hisata et al., 2007; lida et al., 2007; Kurisaki et al., 2008).

We have proposed that the main function of the prion protein is to serve as a dynamic cell surface scaffolding protein, based on its ability to bind a large number of ligands, and to travel across boundaries of distinct plasma membrane domains, as well as to move bidirectionally between the cell surface and intracellular endocytic compartments. These properties allow for a role of $\mathrm{PrP}^{\mathrm{C}}$ upon both the selection and the kinetics of extracellular and cell surface components of signaling modules, as well as the recruiting of transmembrane components able to convey extracellular signals through the plasma membrane. Such properties are likely to underlie both the varied and often contradictory functions attributed to $\mathrm{PrP}^{\mathrm{C}}$, and the multiple phenotypes that follow modulation of the expression of $\operatorname{PrPC}^{\mathrm{C}}$ (Linden et al., 2008).

The current review underscores the importance of $\mathrm{PrP}^{\mathrm{C}}$ in the coordination of signaling related to neuronal survival and differentiation. The ability of $\mathrm{PrP}^{\mathrm{C}}$ to mediate the assembly of multi-component complexes at the cell surface is likely the basis for its neurotrophic properties, and may be relevant for loss-of-function components of prion diseases (Samaia and Brentani, 1998), in particular those associated with neuronal death. In addition, the wide range of molecular interactions described for $\mathrm{PrP}^{\mathrm{C}}$ suggests that this protein may be relevant for not only the spongiform encephalophaties, but also as an ancillary component of the pathogenesis of other neurodegenerative diseases, and therefore amenable to therapeutic targeting. Further studies should be directed at the unraveling of additional signaling complexes scaffolded by $\mathrm{PrP}^{\mathrm{C}}$, as well as to the role of these molecular assemblies upon both physiological and pathological properties of both the nervous system and other organs (Linden et al., 2008).

\section{Acknowledgements}

Research done in the authors' laboratories, included in this review, was supported by grants and fellowships from FAPESP, CNPq, CAPES, FAPERJ, PRONEX, The Millenium Institutes - Gene Therapy Network/MCT and Toxins/MCT, FINEP, FAPEMIG and NIH-Fogarty Center. R.L. and M.A.M.P. are former fellows of the John Simon Guggenheim Foundation. Fellowships from FAPESP to F.H.B.P, M.H.L. and G.N.M.H. are gratefully acknowledged V.R.M is an International Research Scholar of the Howard Hughes Medical Institute.

\section{References}

Alfa CM, Sunyach C, Slack BE, Fisher A, Vincent B, and Checler F (2007) M1 and M3 muscarinic receptors control physiological processing of cellular prion by modulating ADAM17 phosphorylation and activity. J Neurosci, 27, 4083-4092.

Americo TA, Chiarini LB, and Linden R (2007) Signaling induced by hop/STI-1 depends on endocytosis. Biochem Biophys Res Commun, 358, 620-625.

Azmitia EC (2002) Cajal's hypotheses on neurobiones and neurotropic factor match properties of microtubules and S-100 beta. Prog Brain Res, 136, 87-100.

Azzalin A, Ferrara V, Arias A, Cerri S, Avella D, Pisu MB, Nano R, Bernocchi G, Ferretti L, and Comincini S (2006) Interaction between the cellular prion (PrPC) and the $2 \mathrm{P}$ domain $\mathrm{K}+$ channel TREK-1 protein. Biochem Biophys Res Commun, 346, 108-115.

Bainbridge $\mathrm{J}$ and Walker KB (2005) The normal cellular form of prion protein modulates T cell responses. Immunol Lett, 96, 147-150. 
Baumann F, Tolnay M, Brabeck C, Pahnke J, Kloz U, Niemann HH, Heikenwalder M, Rulicke T, Burkle A, and Aguzzi A (2007) Lethal recessive myelin toxicity of prion protein lacking its central domain. EMBO J, 26, 538-547.

Beringue V, Mallinson G, Kaisar M, Tayebi M, Sattar Z, Jackson G, Anstee D, Collinge J, and Hawke S (2003) Regional heterogeneity of cellular prion protein isoforms in the mouse brain. Brain, 126, 2065-2073.

Bezman N and Koretzky GA (2007) Compartmentalization of ITAM and integrin signaling by adapter molecules. Immunol Rev, 218, 9-28.

Bhattacharyya RP, Remenyi A, Yeh BJ, and Lim WA (2006) Domains, motifs, and scaffolds: the role of modular interactions in the evolution and wiring of cell signaling circuits. Annu Rev Biochem, 75, 655-680.

Blochl A and Blochl R (2007) A cell-biological model of p75NTR signaling. J Neurochem, 102, 289-305.

Borchelt DR, Rogers M, Stahl N, Telling G, and Prusiner SB (1993) Release of the cellular prion protein from cultured cells after loss of its glycoinositol phospholipid anchor. Glycobiology, 3, 319-329.

Brini M, Miuzzo M, Pierobon N, Negro A, and Sorgato MC (2005) The prion protein and its paralogue Doppel affect calcium signaling in Chinese hamster ovary cells. Mol Biol Cell, 16, 2799-2808.

Bueler $\mathrm{H}$, Fischer M, Lang $\mathrm{Y}$, Bluethmann H, Lipp HP, DeArmond SJ, Prusiner SB, Aguet M, and Weissmann C (1992) Normal development and behaviour of mice lacking the neuronal cell- surface PrP protein. Nature, 356, 577-582.

Cabral AL, Lee KS, and Martins VR (2002) Regulation of the cellular prion protein gene expression depends on chromatin conformation. J Biol Chem, 277, 5675-5682.

Caetano FA, Lopes MH, Hajj GN, Machado CF, Pinto AC, Magalhaes AC, Vieira MP, Americo TA, Massensini AR, Priola SA, Vorberg I, Gomez MV, Linden R, Prado VF, Martins VR, and Prado MA (2008) Endocytosis of prion protein is required for ERK1/2 signaling induced by stressinducible protein 1. J Neurosci, 28, 6691-6702.

Calixto JB, Medeiros R, Fernandes ES, Ferreira J, Cabrini DA, and Campos MM (2004) Kinin B1 receptors: key G-protein-coupled receptors and their role in inflammatory and painful processes. Br J Pharmacol, 143, 803-818.

Calzolai L, Lysek DA, Perez DR, Guntert P, and Wuthrich K (2005) Prion protein NMR structures of chickens, turtles, and frogs. Proc Natl Acad Sci U S A, 102, 651-655.

Caughey B, Brown K, Raymond GJ, Katzenstein GE, and Thresher W (1994) Binding of the protease-sensitive form of $\operatorname{PrP}$ (prion protein) to sulfated glycosaminoglycan and congo red [corrected]. J Virol, 68, 2135-2141.

Caughey B, Caughey WS, Kocisko DA, Lee KS, Silveira JR, and Morrey JD (2006) Prions and transmissible spongiform encephalopathy (TSE) chemotherapeutics: A common mechanism for anti-TSE compounds? Acc Chem Res, 39, 646-653.

Chao MV (2003) Neurotrophins and their receptors: a convergence point for many signalling pathways. Nat Rev Neurosci, 4, 299-309.

Chao MV and Bothwell M (2002) Neurotrophins: to cleave or not to cleave. Neuron, 33, 9-12.

Chen S, Mange A, Dong L, Lehmann S, and Schachner $M$ (2003) Prion protein as trans-interacting partner for neurons is involved in neurite outgrowth and neuronal survival. Mol Cell Neurosci, 22, 227-233.
Chen SG, Teplow DB, Parchi P, Teller JK, Gambetti P, and utilio-Gambetti $L$ (1995) Truncated forms of the human prion protein in normal brain and in prion diseases. J Biol Chem, 270, 19173-19180.

Chiarini LB, Freitas AR, Zanata SM, Brentani RR, Martins VR, and Linden $\mathrm{R}$ (2002) Cellular prion protein transduces neuroprotective signals. EMBO J, 21, 3317-3326.

Cisse MA, Sunyach C, Lefranc-Jullien S, Postina R, Vincent $B$, and Checler $F$ (2005) The disintegrin ADAM9 indirectly contributes to the physiological processing of cellular prion by modulating ADAM10 activity. J Biol Chem, 280, 40624-40631.

Clegg DO, Wingerd KL, Hikita ST, and Tolhurst EC (2003) Integrins in the development, function and dysfunction of the nervous system. Front Biosci, 8, d723-d750.

Coitinho AS, Freitas AR, Lopes MH, Hajj GN, Roesler R, Walz R, Rossato JI, Cammarota M, Izquierdo I, Martins VR, and Brentani RR (2006) The interaction between prion protein and laminin modulates memory consolidation. Eur J Neurosci, 24, 3255-3264.

Coitinho AS, Lopes MH, Hajj GN, Rossato JI, Freitas AR, Castro CC, Cammarota M, Brentani RR, Izquierdo I, and Martins VR (2007) Short-term memory formation and long-term memory consolidation are enhanced by cellular prion association to stress-inducible protein 1. Neurobiol Dis, 26, 282-290.

Coitinho AS, Roesler R, Martins VR, Brentani RR, and Izquierdo I (2003) Cellular prion protein ablation impairs behavior as a function of age. Neuroreport, 14, 1375-1379.

Colling SB, Collinge J, and Jefferys JG (1996) Hippocampal slices from prion protein null mice: disrupted $\mathrm{Ca}(2+)$ activated K+ currents. Neurosci Lett, 209, 49-52.

Collinge J, Whittington MA, Sidle KC, Smith CJ, Palmer MS, Clarke AR, and Jefferys JG (1994) Prion protein is necessary for normal synaptic function. Nature, 370 , 295-297.

Colognato $\mathrm{H}$, ffrench-Constant C, and Feltri ML (2005) Human diseases reveal novel roles for neural laminins. Trends Neurosci, 28, 480-486.

Colognato $\mathrm{H}$ and Yurchenco PD (2000) Form and function: the laminin family of heterotrimers. Dev Dyn, 218, 213-234.

Conese M, Nykjaer A, Petersen CM, Cremona O, Pardi R, Andreasen PA, Gliemann J, Christensen El, and Blasi F (1995) alpha-2 Macroglobulin receptor/Ldl receptorrelated protein(Lrp)-dependent internalization of the urokinase receptor. J Cell Biol, 131, 1609-1622.

Cosker KE, Courchesne SL, and Segal RA (2008) Action in the axon: generation and transport of signaling endosomes. Curr Opin Neurobiol. 18, 270-275.

Coulpier M, Messiaen S, Boucreaux D, and Eloit M (2006) Axotomy-induced motoneuron death is delayed in mice overexpressing PrPc. Neuroscience, 141, 1827-1834.

Criado JR, Sanchez-Alavez M, Conti B, Giacchino JL, Wills DN, Henriksen SJ, Race R, Manson JC, Chesebro B, and Oldstone MB (2005) Mice devoid of prion protein have cognitive deficits that are rescued by reconstitution of $\mathrm{PrP}$ in neurons. Neurobiol Dis, 19, 255-265.

Czekay RP, Kuemmel TA, Orlando RA, and Farquhar MG (2001) Direct binding of occupied urokinase receptor (UPAR) to LDL receptor-related protein is required for endocytosis of UPAR and regulation of cell surface urokinase activity. Mol Biol Cell, 12, 1467-1479. 
Danielisova V, Gottlieb M, Nemethova M, and Burda J (2008) Effects of bradykinin postconditioning on endogenous antioxidant enzyme activity after transient forebrain ischemia in rat. Neurochem Res, 33, 1057-1064.

Datson NA, Morsink MC, Meijer OC, and de Kloet ER (2008) Central corticosteroid actions: Search for gene targets. Eur J Pharmacol, 583, 272-289.

Davies AM (1996) The neurotrophic hypothesis: where does it stand? Philos Trans R Soc Lond B Biol Sci, 351, 389-394.

de Almeida CJ, Chiarini LB, da Silva JP, PM ES, Martins MA, and Linden $R$ (2005) The cellular prion protein modulates phagocytosis and inflammatory response. J Leukoc Biol, 77, 238-246.

De AA and Georges-Labouesse E (2000) Integrin and ECM functions: roles in vertebrate development. Trends Genet, 16, 389-395.

DeArmond SJ, Qiu Y, Sanchez H, Spilman PR, NinchakCasey A, Alonso D, and Daggett V (1999) PrPc glycoform heterogeneity as a function of brain region: implications for selective targeting of neurons by prion strains. J Neuropathol Exp Neurol, 58, 1000-1009.

DeArmond SJ, Sanchez H, Yehiely F, Qiu Y, Ninchak-Casey A, Daggett V, Camerino AP, Cayetano J, Rogers M, Groth D, Torchia M, Tremblay P, Scott MR, Cohen FE, and Prusiner SB (1997) Selective neuronal targeting in prion disease. Neuron, 19, 1337-1348.

Denda S and Reichardt LF (2007) Studies on integrins in the nervous system. Methods Enzymol, 426, 203-221.

Ditlevsen DK, Povlsen GK, Berezin V, and Bock E (2008) NCAM-induced intracellular signaling revisited. J Neurosci Res, 86, 727-743.

Dohlman HG (2008) A scaffold makes the switch. Sci Signal, 1, e46.

Dupuis L, Mbebi C, Gonzalez de Aguilar JL, Rene F, Muller A, de TM, and Loeffler JP (2002) Loss of prion protein in a transgenic model of amyotrophic lateral sclerosis. Mol Cell Neurosci, 19, 216-224.

Eberl H, Tittmann P, and Glockshuber R (2004) Characterization of recombinant, membrane-attached full-length prion protein. J Biol Chem, 279, 25058-25065.

Fagan KA, Graf RA, Tolman S, Schaack J, and Cooper DM (2000) Regulation of a Ca2+-sensitive adenylyl cyclase in an excitable cell. Role of voltage-gated versus capacitative Ca2+ entry. J Biol Chem, 275, 40187-40194.

Ferguson SS (2001) Evolving concepts in G protein-coupled receptor endocytosis: the role in receptor desensitization and signaling. Pharmacol Rev, 53, 1-24.

Fevrier B, Vilette D, Archer F, Loew D, Faigle W, Vidal M, Laude $H$, and Raposo G (2004) Cells release prions in association with exosomes. Proc Natl Acad Sci U S A, 101, 9683-9688.

Fink M, Duprat F, Lesage F, Reyes R, Romey G, Heurteaux C, and Lazdunski M (1996) Cloning, functional expression and brain localization of a novel unconventional outward rectifier K+ channel. EMBO J, 15, 6854-6862.

Fivaz M, Vilbois F, Thurnheer S, Pasquali C, Abrami L, Bickel PE, Parton RG, and van der Goot FG (2002) Differential sorting and fate of endocytosed GPI-anchored proteins. EMBO J, 21, 3989-4000.

Franks NP and Honore E (2004) The TREK K2P channels and their role in general anaesthesia and neuroprotection. Trends Pharmacol Sci, 25, 601-608.
Freire E, Gomes FC, Linden R, Neto VM, and CoelhoSampaio $T$ (2002) Structure of laminin substrate modulates cellular signaling for neuritogenesis. J Cell Sci, 115, 4867-4876.

Fuhrmann M, Bittner T, Mitteregger G, Haider N, Moosmang S, Kretzschmar H, and Herms J (2006) Loss of the cellular prion protein affects the $\mathrm{Ca} 2+$ homeostasis in hippocampal CA1 neurons. J Neurochem, 98, 1876-1885.

Gauczynski S, Peyrin JM, Haik S, Leucht C, Hundt C, Rieger $\mathrm{R}$, Krasemann S, Deslys JP, Dormont D, Lasmezas CI, and Weiss S (2001) The 37-kDa/67-kDa laminin receptor acts as the cell-surface receptor for the cellular prion protein. EMBO J, 20, 5863-5875.

Giacomello M, Drago I, Pizzo P, and Pozzan T (2007) Mitochondrial $\mathrm{Ca} 2+$ as a key regulator of cell life and death. Cell Death Differ, 14, 1267-1274.

Gorodinsky A and Harris DA (1995) Glycolipid-anchored proteins in neuroblastoma cells form detergent-resistant complexes without caveolin. J Cell Biol, 129, 619-627.

Graner E, Mercadante AF, Zanata SM, Forlenza OV, Cabral AL, Veiga SS, Juliano MA, Roesler R, Walz R, Minetti A, Izquierdo I, Martins VR, and Brentani, RR (2000a) Cellular prion protein binds laminin and mediates neuritogenesis. Brain Res Mol Brain Res, 76, 85-92.

Graner E, Mercadante AF, Zanata SM, Martins VR, Jay DG, and Brentani RR (2000b) Laminin-induced PC-12 cell differentiation is inhibited following laser inactivation of cellular prion protein. FEBS Lett, 482, 257-260.

Grimpe B and Silver J (2002) The extracellular matrix in axon regeneration. Prog Brain Res, 137, 333-349.

Hajj GN, Lopes MH, Mercadante AF, Veiga SS, da Silveira RB, Santos TG, Ribeiro KC, Juliano MA, Jacchieri SG, Zanata SM, and Martins VR (2007) Cellular prion protein interaction with vitronectin supports axonal growth and is compensated by integrins. J Cell Sci, 120, 1915-1926.

Haraguchi T, Fisher S, Olofsson S, Endo T, Groth D, Tarentino A, Borchelt DR, Teplow D, Hood L, Burlingame A, and . (1989) Asparagine-linked glycosylation of the scrapie and cellular prion proteins. Arch Biochem Biophys, 274, 1-13.

Harris DA, Huber MT, van DP, Shyng SL, Chait BT, and Wang R (1993) Processing of a cellular prion protein: identification of $\mathrm{N}$ - and C-terminal cleavage sites. Biochemistry, 32, 1009-1016.

Hegde RS, Mastrianni JA, Scott MR, DeFea KA, Tremblay P, Torchia M, DeArmond SJ, Prusiner SB, and Lingappa VR (1998) A transmembrane form of the prion protein in neurodegenerative disease. Science, 279, 827-834.

Heppner FL, Musahl C, Arrighi I, Klein MA, Rulicke T, Oesch B, Zinkernagel RM, Kalinke $U$, and Aguzzi A (2001) Prevention of scrapie pathogenesis by transgenic expression of anti-prion protein antibodies. Science, 294 , 178-182.

Herms JW, Korte S, Gall S, Schneider I, Dunker S, and Kretzschmar HA (2000) Altered intracellular calcium homeostasis in cerebellar granule cells of prion proteindeficient mice. J Neurochem, 75, 1487-1492.

Herms JW, Tings T, Dunker S, and Kretzschmar HA (2001) Prion protein affects $\mathrm{Ca} 2+$-activated $\mathrm{K}+$ currents in cerebellar purkinje cells. Neurobiol Dis, 8, 324-330.

Hicks MR, Gill AC, Bath IK, Rullay AK, Sylvester ID, Crout $\mathrm{DH}$, and Pinheiro TJ (2006) Synthesis and structural characterization of a mimetic membrane-anchored prion protein. FEBS J, 273, 1285-1299. 
Hisata S, Sakisaka T, Baba T, Yamada T, Aoki K, Matsuda M, and Takai Y (2007) Rap1-PDZ-GEF1 interacts with a neurotrophin receptor at late endosomes, leading to sustained activation of Rap1 and ERK and neurite outgrowth. J Cell Biol, 178, 843-860.

Hornemann S, Schorn C, and Wuthrich K (2004) NMR structure of the bovine prion protein isolated from healthy calf brains. EMBO Rep, 5, 1159-1164.

Hossain WA, D'Sa C, and Morest DK (2008) Interactive roles of fibroblast growth factor 2 and neurotrophin 3 in the sequence of migration, process outgrowth, and axonal differentiation of mouse cochlear ganglion cells. J Neurosci Res, 86, 2376-2391.

Howe CL and Mobley WC (2005) Long-distance retrograde neurotrophic signaling. Curr Opin Neurobiol, 15, 40-48.

Huang EJ and Reichardt LF (2003) Trk receptors: roles in neuronal signal transduction. Annu Rev Biochem, 72, 609-642.

Hundt C, Peyrin JM, Haik S, Gauczynski S, Leucht C, Rieger $\mathrm{R}$, Riley ML, Deslys JP, Dormont D, Lasmezas $\mathrm{Cl}$, and Weiss S (2001) Identification of interaction domains of the prion protein with its $37-\mathrm{kDa} / 67-\mathrm{kDa}$ laminin receptor. EMBO J, 20, 5876-5886.

Ibanez CF (2007) Message in a bottle: long-range retrograde signaling in the nervous system. Trends Cell Biol, 17, 519-528.

lida J, Ishizaki H, Okamoto-Tanaka M, Kawata A, Sumita K, Ohgake S, Sato Y, Yorifuji H, Nukina N, Ohashi K, Mizuno K, Tsutsumi T, Mizoguchi A, Miyoshi J, Takai Y, and Hata Y (2007) Synaptic scaffolding molecule alpha is a scaffold to mediate N-methyl-D-aspartate receptor-dependent RhoA activation in dendrites. Mol Cell Biol, 27, 4388-4405.

Iwakura Y, Nawa H, Sora I, and Chao MV (2008) Dopamine D1 receptor-induced signaling through TrkB receptors in striatal neurons. J Biol Chem, 283, 1579915806.

Jarnaess E and Tasken K (2007) Spatiotemporal control of cAMP signalling processes by anchored signalling complexes. Biochem Soc Trans, 35, 931-937.

Jeanneteau F, Garabedian MJ, and Chao MV (2008) Activation of Trk neurotrophin receptors by glucocorticoids provides a neuroprotective effect. Proc Natl Acad Sci U S A, 105, 4862-4867.

Jodoin J, Laroche-Pierre S, Goodyer CG, and Leblanc AC (2007) Defective retrotranslocation causes loss of antiBax function in human familial prion protein mutants. J Neurosci, 27, 5081-5091.

Kalb R (2005) The protean actions of neurotrophins and their receptors on the life and death of neurons. Trends Neurosci, 28, 5-11.

Kanaani J, Prusiner SB, Diacovo J, Baekkeskov S, and Legname G (2005) Recombinant prion protein induces rapid polarization and development of synapses in embryonic rat hippocampal neurons in vitro. J Neurochem, 95, 13731386.

Katanaev VL, Solis GP, Hausmann G, Buestorf S, Katanayeva N, Schrock Y, Stuermer CA, and Basler K (2008) Reggie-1/flotillin-2 promotes secretion of the longrange signalling forms of Wingless and Hedgehog in Drosophila. EMBO J, 27, 509-521.

Khosravani H, Zhang Y, Tsutsui S, Hameed S, Altier C, Hamid J, Chen L, Villemaire M, Ali Z, Jirik FR, and Zamponi GW (2008) Prion protein attenuates excitotoxicity by inhibiting NMDA receptors. J Cell Biol, 181, 551-565.
Kleene R, Loers G, Langer J, Frobert Y, Buck F, and Schachner M (2007) Prion protein regulates glutamatedependent lactate transport of astrocytes. J Neurosci, 27, 12331-12340.

Kocisko DA, VaillantA, Lee KS, Arnold KM, Bertholet N, Race RE, Olsen EA, Juteau JM, and Caughey B (2006) Potent antiscrapie activities of degenerate phosphorothioate oligonucleotides. Antimicrob Agents Chemother, 50, 10341044.

Kong Q, Surewicz WK, Petersen RB, Zou W, Chen SG, Gambetti P, Parchi P, Capellari S, Goldfarb L, Montagna P, Lugaresi E, Piccardo P, and Ghetti B (2003). Inherited Prion Diseases. In Stanley B Prusiner (Ed.), Prion Biology and Diseases, . John Inglis, pp. 673-775.

Krieglstein K and Unsicker K (1996) Proteins from chromaffin granules promote survival of dorsal root ganglionic neurons: comparison with neurotrophins. Brain Res Dev Brain Res, 93, 10-17.

Kristensson K, Feuerstein B, Taraboulos A, Hyun WC, Prusiner SB, and DeArmond SJ (1993) Scrapie prions alter receptor-mediated calcium responses in cultured cells. Neurology, 43, 2335-2341.

Kurisaki A, Inoue I, Kurisaki K, Yamakawa N, Tsuchida K, and Sugino H (2008) Activin induces long-lasting N-methyl-Daspartate receptor activation via scaffolding PDZ protein activin receptor interacting protein 1. Neuroscience, 151, 1225-1235.

Kuwahara C, Takeuchi AM, Nishimura T, Haraguchi K, Kubosaki A, Matsumoto Y, Saeki K, Matsumoto Y, Yokoyama T, Itohara S, and Onodera T (1999) Prions prevent neuronal cell-line death. Nature, 400, 225-226.

Laffont-Proust I, Faucheux BA, Hassig R, Sazdovitch V, Simon S, Grassi J, Hauw JJ, Moya KL, and Haik S (2005) The $\mathrm{N}$-terminal cleavage of cellular prion protein in the human brain. FEBS Lett, 579, 6333-6337.

Landolt HP, Glatzel M, Blattler T, Achermann P, Roth C, Mathis J, Weis J, Tobler I, Aguzzi A, and Bassetti CL (2006) Sleep-wake disturbances in sporadic CreutzfeldtJakob disease. Neurology, 66, 1418-1424.

Lauren J, Gimbel DA, Nygaard HB, Gilbert JW, and Strittmatter SM (2009) Cellular prion protein mediates impairment of synaptic plasticity by amyloid-beta oligomers. Nature, 457, 1128-1132.

Lee FS, Rajagopal R, Kim AH, Chang PC, and Chao MV (2002) Activation of Trk neurotrophin receptor signaling by pituitary adenylate cyclase-activating polypeptides. J Biol Chem, 277, 9096-9102.

Lee KJ, Panzera A, Rogawski D, Greene LE, and Eisenberg $\mathrm{E}(2007 a)$ Cellular prion protein (PrPC) protects neuronal cells from the effect of huntingtin aggregation. J Cell Sci, 120, 2663-2671.

Lee KS, Magalhaes AC, Zanata SM, Brentani RR, Martins VR, and Prado MA (2001) Internalization of mammalian fluorescent cellular prion protein and $\mathrm{N}$-terminal deletion mutants in living cells. J Neurochem, 79, 79-87.

Lee KS, Raymond LD, Schoen B, Raymond GJ, Kett L, Moore RA, Johnson LM, Taubner L, Speare JO, Onwubiko HA, Baron GS, Caughey WS, and Caughey B (2007b) Hemin interactions and alterations of the subcellular localization of prion protein. J Biol Chem, 282, 36525-36533.

Lefebvre-Roque M, Kremmer E, Gilch S, Zou WQ, Feraudet C, Gilles CM, Sales N, Grassi J, Gambetti P, Baron T, Schatzl H, and Lasmezas Cl (2007) Toxic effects of 
intracerebral PrP antibody administration during the course of BSE infection in mice. Prion, 1, 198-206.

Levi-Montalcini R (1987) The nerve growth factor 35 years later. Science, 237, 1154-1162.

Levi-Montalcini R and Calissano P (2006) The scientific challenge of the 21st century: from a reductionist to a holistic approach via systems biology. BMC Neurosci, 7 Suppl 1, S1.

Levi-Montalcini R, Skaper SD, Dal TR, Petrelli L, and Leon A (1996) Nerve growth factor: from neurotrophin to neurokine. Trends Neurosci, 19, 514-520.

Levine JM (1992) Historical perspective: the neurotrophic theory of skin ulceration. J Am Geriatr Soc, 40, 1281-1283.

Li A, Christensen HM, Stewart LR, Roth KA, Chiesa R, and Harris DA (2007) Neonatal lethality in transgenic mice expressing prion protein with a deletion of residues 105-125. EMBO J, 26, 548-558.

Liesi P, Narvanen A, Soos J, Sariola H, and Snounou G (1989) Identification of a neurite outgrowth-promoting domain of laminin using synthetic peptides. FEBS Lett, 244, 141-148.

Lima FR, Arantes CP, Muras AG, Nomizo R, Brentani RR, and Martins VR (2007) Cellular prion protein expression in astrocytes modulates neuronal survival and differentiation. J Neurochem. 103, 2164-2176.

Linden R (1994) The survival of developing neurons: a review of afferent control. Neuroscience, 58, 671-682.

Linden R, Martins RA, and Silveira MS (2005) Control of programmed cell death by neurotransmitters and neuropeptides in the developing mammalian retina. Prog Retin Eye Res, 24, 457-491.

Linden R, Martins VR, Prado MA, Cammarota M, Izquierdo I, and Brentani RR (2008) Physiology of the prion protein. Physiol Rev, 88, 673-728.

Lopes MH, Hajj GN, Muras AG, Mancini GL, Castro RM, Ribeiro KC, Brentani RR, Linden R, and Martins VR (2005) Interaction of cellular prion and stress-inducible protein 1 promotes neuritogenesis and neuroprotection by distinct signaling pathways. J Neurosci, 25, 11330-11339.

Lopez GF, Zahn R, Riek R, and Wuthrich K (2000) NMR structure of the bovine prion protein. Proc Natl Acad Sci U S A, 97, 8334-8339.

Luckenbill-Edds L (1997) Laminin and the mechanism of neuronal outgrowth. Brain Res Brain Res Rev, 23, 1-27.

Lysek DA, Schorn C, Nivon LG, Esteve-Moya V, Christen B, Calzolai L, von SC, Fiorito F, Herrmann T, Guntert P, and Wuthrich K (2005) Prion protein NMR structures of cats, dogs, pigs, and sheep. Proc Natl Acad Sci U S A, 102, 640-645.

Magalhaes AC, Silva JA, Lee KS, Martins VR, Prado VF, Ferguson SS, Gomez MV, Brentani RR, and Prado MA (2002) Endocytic intermediates involved with the intracellular trafficking of a fluorescent cellular prion protein. J Biol Chem, 277, 33311-33318.

Maglio LE, Perez MF, Martins VR, Brentani RR, and Ramirez OA (2004) Hippocampal synaptic plasticity in mice devoid of cellular prion protein. Brain Res Mol Brain Res, 131, 58-64.

Malaga-Trillo E, Solis GP, Schrock Y, Geiss C, Luncz L, Thomanetz V, and Stuermer CA (2009) Regulation of embryonic cell adhesion by the prion protein. PLoS Biol, 7, e55.
Mallucci GR, Ratte S, Asante EA, Linehan J, Gowland I, Jefferys JG, and Collinge J (2002) Post-natal knockout of prion protein alters hippocampal CA1 properties, but does not result in neurodegeneration. EMBO J, 21, 202-210.

Mallucci G, Dickinson A, Linehan J, Klohn PC, Brandner $\mathrm{S}$, and Collinge J (2003) Depleting neuronal PrP in prion infection prevents disease and reverses spongiosis. Science, 302, 871-874.

Mallucci GR, White MD, Farmer M, Dickinson A, Khatun $\mathrm{H}$, Powell AD, Brandner S, Jefferys JG, and Collinge J (2007) Targeting cellular prion protein reverses early cognitive deficits and neurophysiological dysfunction in prion-infected mice. Neuron, 53, 325-335.

Manson JC, Clarke AR, Hooper ML, Aitchison L, McConnell I, and Hope J (1994) 129/Ola mice carrying a null mutation in PrP that abolishes mRNA production are developmentally normal. Mol Neurobiol, 8, 121-127.

Marchi S, Rimessi A, Giorgi C, Baldini C, Ferroni L, Rizzuto R, and Pinton P (2008) Akt kinase reducing endoplasmic reticulum $\mathrm{Ca} 2+$ release protects cells from Ca2+-dependent apoptotic stimuli. Biochem Biophys Res Commun, 375, 501-505.

Martins AH, Resende RR, Majumder P, Faria M, Casarini DE, Tarnok A, Colli W, Pesquero JB, and Ulrich H (2005) Neuronal differentiation of P19 embryonal carcinoma cells modulates kinin B2 receptor gene expression and function. J Biol Chem, 280, 19576-19586.

Martins RAand Pearson RA(2008) Control of cell proliferation by neurotransmitters in the developing vertebrate retina. Brain Res, 1192, 37-60.

Martins VR, Graner E, Garcia-Abreu J, de Souza SJ, Mercadante AF, Veiga SS, Zanata SM, Neto VM, and Brentani RR (1997) Complementary hydropathy identifies a cellular prion protein receptor. Nat Med, 3, 1376-1382.

Martins VR, Linden R, Prado MA, Walz R, Sakamoto AC, Izquierdo I, and Brentani RR (2002) Cellular prion protein: on the road for functions. FEBS Lett, 512, 25-28.

Masters CL, Gajdusek DC, and Gibbs CJ, Jr. (1981) Creutzfeldt-Jakob disease virus isolations from the Gerstmann-Straussler syndrome with an analysis of the various forms of amyloid plaque deposition in the virus-induced spongiform encephalopathies. Brain, 104, 559-588.

Mattei V, Barenco MG, Tasciotti V, Garofalo T, Longo A, Boller K, Lower J, Misasi R, Montrasio F, and Sorice M (2009) Paracrine diffusion of $\operatorname{Pr}(\mathrm{C})$ and propagation of prion infectivity by plasma membrane-derived microvesicles. PLoS One, 4, e5057.

McLennan NF, Brennan PM, McNeill A, Davies I, Fotheringham A, Rennison KA, Ritchie D, Brannan $F$, Head MW, Ironside JW, Williams A, and Bell JE (2004) Prion protein accumulation and neuroprotection in hypoxic brain damage. Am J Pathol, 165, 227-235.

Meldrum BS (2000) Glutamate as a neurotransmitter in the brain: review of physiology and pathology. J Nutr, 130, 1007S-1015S.

Middleton G, Hamanoue M, Enokido Y, Wyatt S, Pennica D, Jaffray E, Hay RT, and Davies AM (2000) Cytokineinduced nuclear factor kappa $B$ activation promotes the survival of developing neurons. J Cell Biol, 148, 325-332.

Mitsios N, Saka M, Krupinski J, Pennucci R, Sanfeliu C, Miguel TM, Gaffney J, Kumar P, Kumar S, Sullivan M, and Slevin M (2007) Cellular prion protein is increased in the 
plasma and peri-infarcted brain tissue after acute stroke. J Neurosci Res, 85, 602-611.

Moreno DH (1999) Molecular and functional diversity of voltage-gated calcium channels. Ann N Y Acad Sci, 868, 102-117.

Morillas M, Swietnicki W, Gambetti P, and Surewicz WK (1999) Membrane environment alters the conformational structure of the recombinant human prion protein. J Biol Chem, 274, 36859-36865.

Mouillet-Richard S, Ermonval M, Chebassier C, Laplanche JL, Lehmann S, Launay JM, and Kellermann O (2000) Signal transduction through prion protein. Science, 289, 1925-1928.

Mouillet-Richard S, Pietri M, Schneider B, Vidal C, Mutel V, Launay JM, and Kellermann O (2005) Modulation of serotonergic receptor signaling and crosstalk by prion protein. J Biol Chem, 280, 4592-4601.

Mouillet-Richard S, Schneider B, Pradines E, Pietri M, Ermonval M, Grassi J, Richards JG, Mutel V, Launay JM, and Kellermann O (2007) Cellular prion protein signaling in serotonergic neuronal cells. Ann N Y Acad Sci, 1096, 106-119.

Muramoto T, DeArmond SJ, Scott M, Telling GC, Cohen FE, and Prusiner SB (1997) Heritable disorder resembling neuronal storage disease in mice expressing prion protein with deletion of an alpha-helix. Nat Med, 3, 750-755.

Murrin LC and Talbot JN (2007) RanBPM, a scaffolding protein in the immune and nervous systems. J Neuroimmune Pharmacol, 2, 290-295.

Nagappan G and Lu B (2005) Activity-dependent modulation of the BDNF receptor TrkB: mechanisms and implications. Trends Neurosci, 28, 464-471.

Nakaoka Y, Nishida K, Fujio Y, Izumi M, Terai K, Oshima Y, Sugiyama S, Matsuda S, Koyasu S, Yamauchi-Takihara K, Hirano T, Kawase I, and Hirota H (2003) Activation of gp130 transduces hypertrophic signal through interaction of scaffolding/docking protein Gab1 with tyrosine phosphatase SHP2 in cardiomyocytes. Circ Res, 93, 221-229.

Naslavsky N, Stein R, Yanai A, Friedlander G, and Taraboulos A (1997) Characterization of detergentinsoluble complexes containing the cellular prion protein and its scrapie isoform. J Biol Chem, 272, 6324-6331.

Nazor KE, Seward T, and Telling GC (2007) Motor behavioral and neuropathological deficits in mice deficient for normal prion protein expression. Biochim Biophys Acta, 1772, 645-653.

Nelson J, McFerran NV, Pivato G, Chambers E, Doherty C, Steele D, and Timson DJ (2008) The $67 \mathrm{kDa}$ laminin receptor: structure, function and role in disease. Biosci Rep, 28, 33-48.

Nichols BJ, Kenworthy AK, Polishchuk RS, Lodge R, Roberts TH, Hirschberg K, Phair RD, and Lippincott-Schwartz J (2001) Rapid cycling of lipid raft markers between the cell surface and Golgi complex. J Cell Biol, 153, 529-541.

Nishimura T, Sakudo A, Nakamura I, Lee DC, Taniuchi Y, Saeki K, Matsumoto Y, Ogawa M, Sakaguchi S, Itohara S, and Onodera T (2004) Cellular prion protein regulates intracellular hydrogen peroxide level and prevents copperinduced apoptosis. Biochem Biophys Res Commun, 323, 218-222.

Nykjaer A, Petersen CM, Moller B, Jensen PH, Moestrup SK, Holtet TL, Etzerodt M, Thogersen HC, Munch M,
Andreasen PA, and . (1992) Purified alpha 2macroglobulin receptor/LDL receptor-related protein binds urokinase. plasminogen activator inhibitor type-1 complex. Evidence that the alpha 2-macroglobulin receptor mediates cellular degradation of urokinase receptor-bound complexes. J Biol Chem, 267, 14543-14546.

Oppenheim RW (1989) The neurotrophic theory and naturally occurring motoneuron death. Trends Neurosci, 12, 252-255.

Pantera B, Bini C, Cirri P, Paoli P, Camici G, Manao G, and Caselli A (2009) PrPc activation induces neurite outgrowth and differentiation in PC12 cells: role for caveolin-1 in the signal transduction pathway. J Neurochem, 110, 194-207.

Parizek P, Roeckl C, Weber J, Flechsig E, Aguzzi A, and Raeber AJ (2001) Similar turnover and shedding of the cellular prion protein in primary lymphoid and neuronal cells. J Biol Chem, 276, 44627-44632.

Parkin ET, Watt NT, Hussain I, Eckman EA, Eckman CB, Manson JC, Baybutt HN, Turner AJ, and Hooper NM (2007) Cellular prion protein regulates betasecretase cleavage of the Alzheimer's amyloid precursor protein. Proc Natl Acad Sci U S A, 104, 11062-11067.

Parkin ET, Watt NT, Turner AJ, and Hooper NM (2004) Dual mechanisms for shedding of the cellular prion protein. $J$ Biol Chem, 279, 11170-11178.

Parkyn CJ, Vermeulen EG, Mootoosamy RC, Sunyach C, Jacobsen C, Oxvig C, Moestrup S, Liu Q, Bu G, Jen A, and Morris RJ (2008) LRP1 controls biosynthetic and endocytic trafficking of neuronal prion protein. J Cell Sci, 121, 773-783.

Patel AJ and Honore E (2001) Properties and modulation of mammalian $2 \mathrm{P}$ domain $\mathrm{K}+$ channels. Trends Neurosci, 24, 339-346.

Pauly PC and Harris DA (1998) Copper stimulates endocytosis of the prion protein. J Biol Chem, 273, 33107-33110.

Pawson T and Scott JD (1997) Signaling through scaffold, anchoring, and adaptor proteins. Science, 278, 2075-2080.

Perera WS and Hooper NM (2001) Ablation of the metal ion-induced endocytosis of the prion protein by diseaseassociated mutation of the octarepeat region. Curr Biol, 11, 519-523.

Perini F, Frangione B, and Prelli F (1996) Prion protein released by platelets. Lancet, 347, 1635-1636.

Ping A, Chun ZX, and Xue XY (2005) Bradykinin preconditioning induces protective effects against focal cerebral ischemia in rats. Brain Res, 1059, 105-112.

Pires Neto MA, Braga-de-Souza S, and Lent R (1999) Extracellular matrix molecules play diverse roles in the growth and guidance of central nervous system axons. Braz J Med Biol Res, 32, 633-638.

Pons S and Marti E (2000) Sonic hedgehog synergizes with the extracellular matrix protein vitronectin to induce spinal motor neuron differentiation. Development, 127, 333-342.

Pons S, Trejo JL, Martinez-Morales JR, and Marti E (2001) Vitronectin regulates Sonic hedgehog activity during cerebellum development through CREB phosphorylation. Development, 128, 1481-1492.

Pradines E, Loubet D, Schneider B, Launay JM, Kellermann O, and Mouillet-Richard S (2008) CREB-dependent gene 
regulation by prion protein: Impact on MMP-9 and betadystroglycan. Cell Signal, 20, 2050-2058.

Prado MA, ves-Silva J, Magalhaes AC, Prado VF, Linden R, Martins VR, and Brentani RR (2004) PrPc on the road: trafficking of the cellular prion protein. J Neurochem, 88, 769-781.

Prestori F, Rossi P, Bearzatto B, Laine J, Necchi D, Diwakar S, Schiffmann SN, Axelrad H, and D'Angelo E (2008) Altered neuron excitability and synaptic plasticity in the cerebellar granular layer of juvenile prion protein knockout mice with impaired motor control. J Neurosci, 28, 7091-7103.

Priola SA and Caughey B (1994) Inhibition of scrapieassociated $\operatorname{PrP}$ accumulation. Probing the role of glycosaminoglycans in amyloidogenesis. Mol Neurobiol, 8, 113-120.

Provini F, Vetrugno R, Pierangeli G, Cortelli P, Rizzo G, Filla A, Strisciuglio C, Gallassi R, and Montagna P (2008) Sleep and temperature rhythms in two sisters with P102L Gerstmann-Straussler-Scheinker (GSS) disease. Sleep Med. 10, 374-377.

Radovanovic I, Braun N, Giger OT, Mertz K, Miele G, Prinz M, Navarro B, and Aguzzi A (2005) Truncated prion protein and Doppel are myelinotoxic in the absence of oligodendrocytic PrPC. J Neurosci, 25, 4879-4888.

Rambold AS, Muller V, Ron U, Ben-Tal N, Winklhofer KF, and Tatzelt $J$ (2008) Stress-protective signalling of prion protein is corrupted by scrapie prions. EMBO J, 27, 1974-1984.

Rangel A, Burgaya F, Gavin R, Soriano E, Aguzzi A, and Del Rio JA (2007) Enhanced susceptibility of Prnp-deficient mice to kainate-induced seizures, neuronal apoptosis, and death: Role of AMPA/kainate receptors. J Neurosci Res, 85, 2741-2755.

Rauch U (2004) Extracellular matrix components associated with remodeling processes in brain. Cell Mol Life Sci, 61, 2031-2045.

Rieger R, Edenhofer F, Lasmezas Cl, and Weiss S (1997) The human $37-\mathrm{kDa}$ laminin receptor precursor interacts with the prion protein in eukaryotic cells. Nat Med, 3, 1383-1388.

Riek R, Hornemann S, Wider G, Glockshuber R, and Wuthrich K (1997) NMR characterization of the full-length recombinant murine prion protein, $\operatorname{mPrP}(23231)$. FEBS Lett, 413, 282-288.

Robertson C, Booth SA, Beniac DR, Coulthart MB, Booth TF, and McNicol A (2006) Cellular prion protein is released on exosomes from activated platelets. Blood, 107, 3907-3911.

Rodriguez MM, Peoc'h K, Haik S, Bouchet C, Vernengo L, Manana G, Salamano R, Carrasco L, Lenne M, Beaudry P, Launay JM, and Laplanche JL (2005) A novel mutation $(\mathrm{G} 114 \mathrm{~V})$ in the prion protein gene in a family with inherited prion disease. Neurology, 64, 1455-1457.

Rudd PM, Endo T, Colominas C, Groth D, Wheeler SF, Harvey DJ, Wormald MR, Serban H, Prusiner SB, Kobata A, and Dwek RA (1999) Glycosylation differences between the normal and pathogenic prion protein isoforms. Proc Natl Acad Sci U S A, 96, 13044-13049.

Runeberg-Roos P and Saarma M (2007) Neurotrophic factor receptor RET: structure, cell biology, and inherited diseases. Ann Med, 39, 572-580.
Sadowski MJ, Pankiewicz J, Prelli F, Scholtzova H, Spinner DS, Kascsak RB, Kascsak RJ, and Wisniewski T (2009) Anti-PrP Mab 6D11 suppresses $\operatorname{PrP}(\mathrm{Sc})$ replication in prion infected myeloid precursor line FDC-P1/22L and in the lymphoreticular system in vivo. Neurobiol Dis, 34, 267-278.

Sadri-Vakili G and Cha JH (2006) Histone deacetylase inhibitors: a novel therapeutic approach to Huntington's disease (complex mechanism of neuronal death). Curr Alzheimer Res, 3, 403-408.

Samaia HB and Brentani RR (1998) Can loss-of-function prion-related diseases exist? Mol Psychiatry, 3, 196-197.

Sanford SD, Gatlin JC, Hokfelt T, and Pfenninger KH (2008) Growth cone responses to growth and chemotropic factors. Eur J Neurosci, 28, 268-278.

Santuccione A, Sytnyk V, Leshchyns'ka I, and Schachner M (2005) Prion protein recruits its neuronal receptor NCAM to lipid rafts to activate p59fyn and to enhance neurite outgrowth. J Cell Biol, 169, 341-354.

Sariola Hand Saarma M (2003)Novel functions and signalling pathways for GDNF. J Cell Sci, 116, 3855-3862.

Schmitt-Ulms G, Legname G, Baldwin MA, Ball HL, Bradon N, Bosque PJ, Crossin KL, Edelman GM, DeArmond SJ, Cohen FE, and Prusiner SB (2001) Binding of neural cell adhesion molecules (N-CAMs) to the cellular prion protein. J Mol Biol, 314, 1209-1225.

Schonberger O, Horonchik L, Gabizon R, Papy-Garcia D, Barritault D, and Taraboulos A (2003) Novel heparan mimetics potently inhibit the scrapie prion protein and its endocytosis. Biochem Biophys Res Commun, 312, 473-479.

Schrock Y, Solis GP, and Stuermer CA (2009) Regulation of focal adhesion formation and filopodia extension by the cellular prion protein (PrPC). FEBS Lett, 583, 389-393.

Sharma HS (2007) A select combination of neurotrophins enhances neuroprotection and functional recovery following spinal cord injury. Ann N Y Acad Sci, 1122, 95-111.

Shmerling D, Hegyi I, Fischer M, Blattler T, Brandner S, Gotz J, Rulicke T, Flechsig E, Cozzio A, von MC, Hangartner C, Aguzzi A, and Weissmann C (1998) Expression of aminoterminally truncated PrP in the mouse leading to ataxia and specific cerebellar lesions. Cell, 93, 203-214.

Shyng SL, Heuser JE, and Harris DA (1994) A glycolipidanchored prion protein is endocytosed via clathrin-coated pits. J Cell Biol, 125, 1239-1250.

Shyu WC, Lin SZ, Chiang MF, Ding DC, Li KW, Chen SF, Yang HI, and Li H (2005) Overexpression of PrPC by adenovirus-mediated gene targeting reduces ischemic injury in a stroke rat model. J Neurosci, 25, 8967-8977.

Silva JL, Lima LM, Foguel D, and Cordeiro Y (2008) Intriguing nucleic-acidbinding features of mammalian prion protein. Trends Biochem Sci, 33, 132-140.

Solforosi L, Criado JR, McGavern DB, Wirz S, SanchezAlavez M, Sugama S, DeGiorgio LA, Volpe BT, Wiseman E, Abalos G, Masliah E, Gilden D, Oldstone MB, Conti $B$, and Williamson RA (2004) Cross-linking cellular prion protein triggers neuronal apoptosis in vivo. Science, 303, 1514-1516.

Spudich A, Frigg R, Kilic E, Kilic U, Oesch B, Raeber A, Bassetti CL, and Hermann DM (2005) Aggravation of ischemic brain injury by prion protein deficiency: role of ERK-1/-2 and STAT-1. Neurobiol Dis, 20, 442-449. 
Stuermer CA, Langhorst MF, Wiechers MF, Legler DF, Von Hanwehr SH, Guse AH, and Plattner H (2004) PrPc capping in $\mathrm{T}$ cells promotes its association with the lipid raft proteins reggie- 1 and reggie- 2 and leads to signal transduction. FASEB J, 18, 1731-1733.

Stuermer CA and Plattner H (2005) The 'lipid raft' microdomain proteins reggie-1 and reggie-2 (flotillins) are scaffolds for protein interaction and signalling. Biochem Soc Symp, 109-118.

Sunyach C, Cisse MA, da Costa CA, Vincent B, and Checler $F$ (2007) The C-terminal products of cellular prion protein processing, C1 and C2, exert distinct influence on p53dependent staurosporine-induced caspase-3 activation. J Biol Chem, 282, 1956-1963.

Sunyach C, Jen A, Deng J, Fitzgerald KT, Frobert Y, Grassi J, McCaffrey MW, and Morris R (2003) The mechanism of internalization of glycosylphosphatidylinositol-anchored prion protein. EMBO J, 22, 3591-3601.

Tagliavini F, Prelli F, Porro M, Salmona M, Bugiani O, and Frangione B (1992) A soluble form of prion protein in human cerebrospinal fluid: implications for prion-related encephalopathies. Biochem Biophys Res Commun, 184, 1398-1404.

Tayebi M and Hawke S (2006) Antibody-mediated neuronal apoptosis: therapeutic implications for prion diseases. Immunol Lett, 105, 123-126.

Taylor DR and Hooper NM (2007) The low-density lipoprotein receptor-related protein 1 (LRP1) mediates the endocytosis of the cellular prion protein. Biochem J, 402, 17-23.

Telling GC, Haga T, Torchia M, Tremblay P, DeArmond SJ, and Prusiner SB (1996) Interactions between wild-type and mutant prion proteins modulate neurodegeneration in transgenic mice. Genes Dev, 10, 1736-1750.

Theodosis DT, Piet R, Poulain DA, and Oliet SH (2004) Neuronal, glial and synaptic remodeling in the adult hypothalamus: functional consequences and role of cell surface and extracellular matrix adhesion molecules. Neurochem Int, 45, 491-501.

Theodosis DT, Poulain DA, and Oliet SH (2008) Activitydependent structural and functional plasticity of astrocyteneuron interactions. Physiol Rev, 88, 9831008.

Thiel $G$ and Cibelli G (2002) Regulation of life and death by the zinc finger transcription factor Egr-1. J Cell Physiol, 193, 287-292.

Thoenen H, Hughes RA, and Sendtner M (1993) Trophic support ofmotoneurons: physiological, pathophysiological, and therapeutic implications. Exp Neurol, 124, 47-55.

Tobler I, Deboer T, and Fischer M (1997) Sleep and sleep regulation in normal and prion protein-deficient mice. $\mathrm{J}$ Neurosci, 17, 1869-1879.

Tobler I, Gaus SE, Deboer T, Achermann P, Fischer M, Rulicke T, Moser M, Oesch B, McBride PA, and Manson JC (1996) Altered circadian activity rhythms and sleep in mice devoid of prion protein. Nature, 380, 639-642.

Tzu J and Marinkovich MP (2008) Bridging structure with function: structural, regulatory, and developmental role of laminins. Int J Biochem Cell Biol, 40, 199-214.

Vana $\mathrm{K}$ and Weiss S (2006) A trans-dominant negative $37 \mathrm{kDa} / 67 \mathrm{kDa}$ laminin receptor mutant impairs $\operatorname{PrP}(\mathrm{Sc})$ propagation in scrapie-infected neuronal cells. J Mol Biol, 358, 57-66.
Vella LJ, Greenwood DL, Cappai R, Scheerlinck JP, and Hill AF (2008) Enrichment of prion protein in exosomes derived from ovine cerebral spinal fluid. Vet Immunol Immunopathol, 124, 385-393.

Vey M, Pilkuhn S, Wille H, Nixon R, DeArmond SJ, Smart EJ, Anderson RG, Taraboulos A, and Prusiner SB (1996) Subcellular colocalization of the cellular and scrapie prion proteins in caveolae-like membranous domains. Proc Natl Acad Sci U S A, 93, 14945-14949.

Viard P, Butcher AJ, Halet G, Davies A, Nurnberg B, Heblich F, and Dolphin AC (2004) PI3K promotes voltagedependent calcium channel trafficking to the plasma membrane. Nat Neurosci, 7, 939-946.

Vincent B, Cisse MA, Sunyach C, Guillot-Sestier MV, and Checler $F$ (2008) Regulation of betaAPP and PrPc cleavage by alpha-secretase: mechanistic and therapeutic perspectives. Curr Alzheimer Res, 5, 202-211.

Vincent B, Paitel E, Frobert Y, Lehmann S, Grassi J, and Checler F (2000) Phorbol ester-regulated cleavage of normal prion protein in HEK293 human cells and murine neurons. J Biol Chem, 275, 35612-35616.

Vincent B, Paitel E, Saftig P, Frobert Y, Hartmann D, De SB, Grassi J, Lopez-Perez E, and Checler F (2001) The disintegrins ADAM10 and TACE contribute to the constitutive and phorbol ester-regulated normal cleavage of the cellular prion protein. J Biol Chem, 276, 37743-37746.

Walz R, Amaral OB, Rockenbach IC, Roesler R, Izquierdo I, Cavalheiro EA, Martins VR, and Brentani RR (1999) Increased sensitivity to seizures in mice lacking cellular prion protein. Epilepsia, 40, 1679-1682.

Warner RG, Hundt C, Weiss S, and Turnbull JE (2002) Identification of the heparan sulfate binding sites in the cellular prion protein. J Biol Chem, 277, 18421-18430.

Weise J, Crome O, Sandau R, Schulz-Schaeffer W, Bahr M, and Zerr I (2004) Upregulation of cellular prion protein $(\mathrm{PrPc})$ after focal cerebral ischemia and influence of lesion severity. Neurosci Lett, 372, 146-150.

Weise J, Doeppner TR, Muller T, Wrede A, Schulz-Schaeffer W, Zerr I, Witte OW, and Bahr M (2008) Overexpression of cellular prion protein alters postischemic Erk1/2 phosphorylation but not Akt phosphorylation and protects against focal cerebral ischemia. Restor Neurol Neurosci, 26, 57-64.

Weise J, Sandau R, Schwarting S, Crome O, Wrede A, Schulz-Schaeffer W, Zerr I, and Bahr M (2006) Deletion of cellular prion protein results in reduced Akt activation, enhanced postischemic caspase-3 activation, and exacerbation of ischemic brain injury. Stroke, 37, 1296-1300.

Whatley SA, Powell JF, Politopoulou G, Campbell IC, Brammer MJ, and Percy NS (1995) Regulation of intracellular free calcium levels by the cellular prion protein. Neuroreport, 6, 2333-2337.

White AR, Enever P, Tayebi M, Mushens R, Linehan J, Brandner S, Anstee D, Collinge J, and Hawke S (2003) Monoclonal antibodies inhibit prion replication and delay the development of prion disease. Nature, 422, 80-83.

White MD, Farmer M, Mirabile I, Brandner S, Collinge J, and Mallucci GR (2008) Single treatment with RNAi against prion protein rescues early neuronal dysfunction and prolongs survival in mice with prion disease. Proc Natl Acad Sci U S A, 105, 
Wiese S, Jablonka S, Holtmann B, Orel N, Rajagopal R, Chao MV, and Sendtner M (2007) Adenosine receptor A2A-R contributes to motoneuron survival by transactivating the tyrosine kinase receptor TrkB. Proc Natl Acad Sci U S A, 104, 17210-17215.

Williams GR (2008) Neurodevelopmental and neurophysiological actions of thyroid hormone. J Neuroendocrinol, 20, 784-794.

Wong K, Quu Y, Hyun W, Nixon R, VanCleff J, SanchezSalazar J, Prusiner SB, and DeArmond SJ (1996) Decreased receptor-mediated calcium response in prioninfected cells correlates with decreased membrane fluidity and IP3 release. Neurology, 47, 741-750.

Yan-Feng W, Gang L, and Yan-Ting G (2008) Bradykinin preconditioning induces protective effects on the spinal cord ischemic injury of rats. Neurosci Lett, 433, 114-118.

Yano $\mathrm{H}$ and Chao MV (2000) Neurotrophin receptor structure and interactions. Pharm Acta Helv, 74, 253-260.

Ye J, Han J, Shi Q, Zhang BY, Wang GR, Tian C, Gao C, Chen JM, Li CJ, Lui Z, Li XZ, Zhang LZ, and Dong XP (2008) A genetic human prion disease with $\mathrm{G} 114 \mathrm{~V}$ mutation in
PRNP and epidemiological studies in a Chinese family: a case series. J Med Case Reports, 2, 331.

Zahn R, Liu A, Luhrs T, Riek R, von SC, Lopez GF, Billeter M, Calzolai L, Wider G, and Wuthrich K (2000) NMR solution structure of the human prion protein. Proc Natl Acad Sci U S A, 97, 145-150.

Zanata SM, Lopes MH, Mercadante AF, Hajj GN, Chiarini LB, Nomizo R, Freitas AR, Cabral AL, Lee KS, Juliano MA, de Oliveira E, Jachieri SG, Burlingame A, Huang L, Linden R, Brentani RR, and Martins VR (2002) Stressinducible protein 1 is a cell surface ligand for cellular prion that triggers neuroprotection. EMBO J, 21, 3307-3316.

Zhang J, Zhang D, McQuade JS, Behbehani M, Tsien JZ, and Xu M (2002) c-fos regulates neuronal excitability and survival. Nat Genet, 30, 416-420.

Zuber C, Knackmuss S, Rey C, Reusch U, Rottgen P, Frohlich T, Arnold GJ, Pace C, Mitteregger G, Kretzschmar HA, Little M, and Weiss S (2008) Single chain Fv antibodies directed against the $37 \mathrm{kDa} / 67 \mathrm{kDa}$ laminin receptor as therapeutic tools in prion diseases. Mol Immunol, 45, 144-151. 


\section{Further Reading}

Caister Academic Press is a leading academic publisher of advanced texts in microbiology, molecular biology and medical research. Full details of all our publications at caister.com

- MALDI-TOF Mass Spectrometry in Microbiology Edited by: M Kostrzewa, S Schubert (2016) www.caister.com/malditof

- Aspergillus and Penicillium in the Post-genomic Era Edited by: RP Vries, IB Gelber, MR Andersen (2016) www.caister.com/aspergillus2

- The Bacteriocins: Current Knowledge and Future Prospects Edited by: RL Dorit, SM Roy, MA Riley (2016)

www.caister.com/bacteriocins

- Omics in Plant Disease Resistance Edited by: V Bhadauria (2016) www.caister.com/opd

- Acidophiles: Life in Extremely Acidic Environments Edited by: R Quatrini, DB Johnson (2016) www.caister.com/acidophiles

- Climate Change and Microbial Ecology: Current Research and Future Trend

Edited by: J Marxsen (2016)

www.caister.com/climate

- Biofilms in Bioremediation: Current Research and Emerging Technologies

Edited by: G Lear (2016)

www.caister.com/biorem

- Microalgae: Current Research and Applications Edited by: MN Tsaloglou (2016) www.caister.com/microalgae

- Gas Plasma Sterilization in Microbiology: Theory, Applications, Pitfalls and New Perspectives Edited by: H Shintani, A Sakudo (2016) www.caister.com/gasplasma

- Virus Evolution: Current Research and Future Directions Edited by: SC Weaver, M Denison, M Roossinck, et al. (2016) www.caister.com/virusevol

- Arboviruses: Molecular Biology, Evolution and Control Edited by: N Vasilakis, DJ Gubler (2016) www.caister.com/arbo

- Shigella: Molecular and Cellular Biology Edited by: WD Picking, WL Picking (2016) www.caister.com/shigella

-Aquatic Biofilms: Ecology, Water Quality and Wastewater Treatment

Edited by: AM Romaní, H Guasch, MD Balaguer (2016)

www.caister.com/aquaticbiofilms

- Alphaviruses: Current Biology

Edited by: S Mahalingam, L Herrero, B Herring (2016)

www.caister.com/alpha

- Thermophilic Microorganisms

Edited by: F Li (2015)

www.caister.com/thermophile
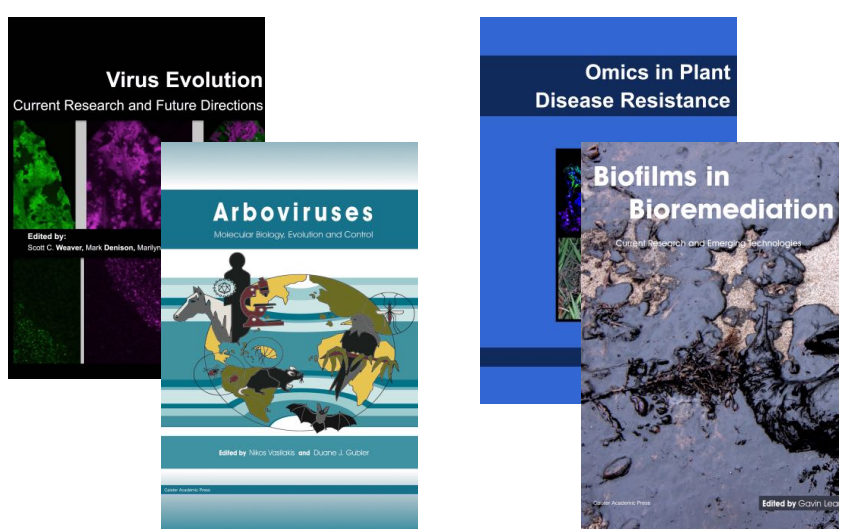
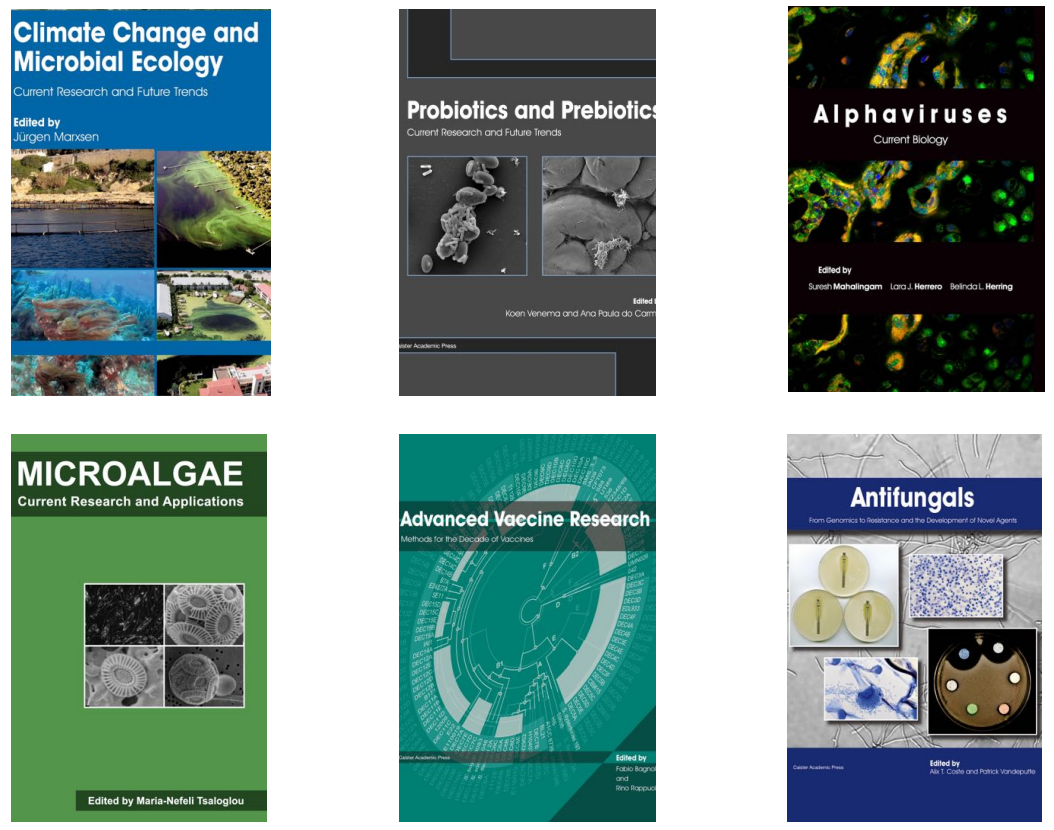

- Flow Cytometry in Microbiology: Technology and Applications Edited by: MG Wilkinson (2015) www.caister.com/flow

- Probiotics and Prebiotics: Current Research and Future Trends Edited by: K Venema, AP Carmo (2015) www.caister.com/probiotics

- Epigenetics: Current Research and Emerging Trends Edited by: BP Chadwick (2015) www.caister.com/epigenetics2015

- Corynebacterium glutamicum: From Systems Biology to Biotechnological Applications

Edited by: A Burkovski (2015)

www.caister.com/cory2

- Advanced Vaccine Research Methods for the Decade of Vaccines

Edited by: F Bagnoli, R Rappuoli (2015)

www.caister.com/vaccines

- Antifungals: From Genomics to Resistance and the Development of Novel Agents

Edited by: AT Coste, P Vandeputte (2015)

www.caister.com/antifungals

- Bacteria-Plant Interactions: Advanced Research and Future Trends Edited by: J Murillo, BA Vinatzer, RW Jackson, et al. (2015) www.caister.com/bacteria-plant

\section{- Aeromonas}

Edited by: J Graf (2015)

www.caister.com/aeromonas

- Antibiotics: Current Innovations and Future Trends

Edited by: S Sánchez, AL Demain (2015)

www.caister.com/antibiotics

- Leishmania: Current Biology and Contro Edited by: S Adak, R Datta (2015) www.caister.com/leish2

- Acanthamoeba: Biology and Pathogenesis (2nd edition) Author: NA Khan (2015)

www.caister.com/acanthamoeba2

- Microarrays: Current Technology, Innovations and Applications Edited by: Z He (2014)

www.caister.com/microarrays2

- Metagenomics of the Microbial Nitrogen Cycle: Theory, Methods and Applications

Edited by: D Marco (2014)

www.caister.com/n2 